\title{
Effect of shielding gas on the properties of CP titanium Grade 2 laser weld joints
}

\author{
M. Vyskoč ${ }^{1}$, M. Dománková ${ }^{2}$, M. Sahul ${ }^{2}$, M. Vyskočováa ${ }^{1}$ \\ ${ }^{1}$ Slovak University of Technology in Bratislava, Faculty of Materials Science and Technology in Trnava, \\ Institute of Productions Technologies, J. Bottu 25, 91724 Trnava, Slovak Republic \\ ${ }^{2}$ Slovak University of Technology in Bratislava, Faculty of Materials Science and Technology in Trnava, \\ Institute of Materials Science, J. Bottu 25, 91724 Trnava, Slovak Republic
}

Received 21 February 2018, received in revised form 14 April 2019, accepted 15 April 2019

\begin{abstract}
The paper deals with the evaluation of the shielding gas influence on the properties of titanium Grade 2 weld joints produced with disk laser. Butt weld joints were produced under different shielding gas types, namely $\mathrm{Ar}, \mathrm{He}, \mathrm{Ar}+5$ vol. $\% \mathrm{He}, \mathrm{Ar}+30 \mathrm{vol} . \% \mathrm{He}$, and without shielding weld pool. Light and electron microscopy, microhardness measurements, computed tomography, and tensile testing were used for evaluation of weld joint properties. He-shielded weld joints were the narrowest ones.

On the other hand, Ar-shielded weld joints exhibited the largest weld width. The choice of shielding gas had a significant influence on the porosity of welds. The lowest porosity was observed in the weld joint produced in Ar with the addition of 30 vol.\% He shielding atmosphere (only $0.03 \%$ ), while the highest level of porosity was detected in weld joint produced without shielding gas $(0.76 \%)$. Except for unshielded titanium Grade 2 weld joint, the lowest tensile strength was recorded in Ar-shielded weld joints. On the contrary, the highest average microhardness, except unshielded weld joint, was measured in He-shielded weld joints.
\end{abstract}

Ke y w or d s: disk laser, laser welding, commercially pure titanium Grade 2, shielding gas, porosity

\section{Introduction}

Common fusion welding processes such as inert tungsten gas, metal inert gas (TIG, MIG, etc.), which are widely used for welding of titanium sheets, have large heat affected zone (HAZ), greater distortion and residual stress, wider weld seam and a higher risk of contamination, etc. From mechanical properties point of view, a narrower heat-affected zone, less distortion, and narrower weld seam are required for a better weld joint $[1-3]$. Laser beam welding is a fusion joining process that relies on the radiant energy produced to heat and melt the base materials to be joined [4]. In particular, a single-mode laser with very small laser spot sizes provides high intensities and allows very deep penetration into metallic materials [5-7]. Various parameters such as power density, welding speed, beam diameter, shielding gas and its flow rate, defocusing distance, beam angle, etc. have been explored to improve the quality of a continuous laser beam welding (LBW). For example, it has been observed that the depth of penetration, bead width, and area of penetration decrease with increasing welding speed and increase with increasing laser power. Similarly, both hardness and strength increase with increasing welding speed or decreasing laser power $[3,8,9]$. Another innovative method of welding with a highly concentrated energy source is an electron beam, but this technique presents the disadvantage that vacuum is needed; also, the process involves X-ray emission [1, 10]. Light metals and their alloys are important construction materials with a high strength-to-weight ratio $[11,12]$. The strength of commercially pure (CP) $\mathrm{Ti}$ is relatively lower than that of most other titanium alloys, but it has the best weldability. Typical yield strength ranged from 170 to $480 \mathrm{MPa}$. It came from

*Corresponding author: e-mail address: maros.vyskoc@stuba.sk 
the strengthening elements, i.e., oxygen and nitrogen in the form of $\alpha$-phase accompanied by some minor $\beta$-phase due to the presence of Fe $[13-15]$. To date, under optimum processing conditions, the strength of the laser-welded titanium alloys can be close to that of the original material [16]. The mechanical properties of the fusion welded joint are frequently related to the microstructure in the weld, which is strongly influenced by both the solidification and the solid phase transformation for pure titanium. In addition, it is commonly accepted that the mechanical properties of pure titanium are also dependent on the microelement contents and the grain orientation due to the hexagonal close-packed structure [17-21]. Various authors have reported welding characteristics of CP Ti. Karpagaraj et al. [22] performed gas tungsten arc welding (GTAW) on CP Ti sheets with a thickness of 1.6 and $2 \mathrm{~mm}$ containing equiaxed alpha phase grains with the presence of fine and disperse precipitation of beta phase. Due to the thermal cycle, the equiaxed grains had grown larger in the HAZ. Compared to the microstructure of the HAZ, there is an inhomogeneous growth of microstructure at the fusion zone (FZ). FZ of the weld bead obtained in GTAW is fairly wide, and it is differentiable. Based on the microstructural studies, the degree of grain coarsening decreases as one moves farther from the FZ to the base metal (BM). Gorinin et al. [23] reported a huge difference in microstructures between fast-cooled $\left(500{ }^{\circ} \mathrm{C} \mathrm{s}^{-1}\right)$ and slow-cooled $\left(20^{\circ} \mathrm{C} \mathrm{s}^{-1}\right) \mathrm{CP}$ Ti weld joint samples. The fast-cooled sample had needle (martensite-like structure) and lamellar-shaped $\alpha$-phase, while the slowcooled sample showed a coarse acicular $\alpha$. The HAZ consists of equiaxed transformed $\beta$ grains which increase in size as the FZ is approached. Within these grains, colonies of $\alpha$-phases are present. Temperatures of over $500{ }^{\circ} \mathrm{C}$ lead to absorption of deleterious gases such as oxygen, nitrogen, and hydrogen in the welding seam, leading to lower mechanical strength. Slower cooling due to high heat input in the welding of titanium and its alloys results in grain coarsening and porosity formation in the welding seam. Grain coarsening and porosities cause lower mechanical strength, especially in welded joints. In welding titanium and its alloys, a narrow welding seam and a microstructure made of fine grains should be achieved by lowering the heat input transfer to the weld zone and increasing the cooling rate. On the other hand, very fast cooling conditions lead to weld metal microstructures that are completely martensitic in nature and thus have a lower toughness [24-27]. Cui Li et al. [28] also observed a significant grain coarsening occurred in the HAZ immediately adjacent to the base metal, and the degree of grain coarsening increases as the grains move towards the centre of the fusion zone. They also pointed out that higher welding speed $\left(5 \mathrm{~m} \mathrm{~min}^{-1}\right.$ vs. $\left.4 \mathrm{~m} \mathrm{~min}^{-1}\right)$ resulted in fine-grained aci- cular alpha in the weld centreline because the higher welding speed leads to higher cooling rate. Lathabai et al. [29] reported columnar grains in the fusion zone which were significantly coarser than those observed in the HAZ and base metal. The columnar grains in the fusion zone were a result of epitaxial growth from the HAZ. The HAZ consisted of equiaxed transformed $\beta$ grains which increased in size as the FZ was approached. Colonies of $\alpha$-phases were present within these grains. They also reported that hardness across the BM-HAZ-FZ was comparable. Note that all the tensile samples fractured at the weld area. Akman investigated the influence of the ratio between pulse energy and pulse duration on depth penetration of laser welded titanium alloy joints. It was shown how the control of the power output could influence the geometry of the welding bead [30]. Mitchell et al. [31] conducted electron beam welding on a $1.6 \mathrm{~mm}$ thick $\mathrm{CP} \mathrm{Ti}$ and found the hardness to be comparable between the weld zones (HAZ and FZ) and the BM. The base metal had a yield strength (YS) of $630 \mathrm{MPa}$, ultimate tensile strength (UTS) of $695 \mathrm{MPa}$ and elongation of around $27 \%$. Following welding caused that the YS dropped to $530 \mathrm{MPa}$, UTS reduced to $660 \mathrm{MPa}$ and elongation to $22 \%$. The tensile tested samples fractured at the BM suggesting reliable weld joints. In brief, typically $\mathrm{CP} \mathrm{Ti}$ welds have coarse columnar grains in the fusion zones (FZ) compared with the heat affected zones (HAZ) and the base metal (BM). In laser welding, shielding gas plays an important role in minimizing the weld porosity and increasing the penetration depth [32]. To protect the mechanical properties of titanium alloys during laser welding, gas shielding is of more importance to prevent embitterment of the weld region and also to ensure losses in ductility. Molten material has gas bubbles which cannot escape before solidification what is the main reason for the porosity problem [33]. Molten pool instabilities in the root area may cause gas bubbles. The high affinity of titanium to oxygen can give rise to the formation of an oxide layer on the melt very quickly, which impedes gas bubbles escape $[34,35]$. In deep penetration welding, the weld depth is increased, but due to the formation of the gaseous keyhole, the risk of process defects is increased. This can lead back to instabilities in the keyhole-like constriction and collapse. Furthermore, porosity can be caused by the evaporation of solved gases in the liquid titanium which degas during cooling [36]. Torkamany et al. showed that weld porosity was formed in the pulsed laser welded joints of pure $\mathrm{Ti}$ [37]. The porosity of weld metal also decreases the loading area and therefore affects strength, toughness, fatigue resistance, and corrosion resistance $[38,39]$. The shielding gases have an important effect on the formation of the weld bead and the penetration. The application of different shielding gases can result in different penetration and weld bead profiles. Pores 
can be the initiation points for crack propagation in the weld joint and can considerably decrease the life cycle of joints under dynamic loads. It is clear from the above that appropriate selection of process gases is an essential consideration for efficiency, quality, and overall weld acceptability [40]. Argon (Ar) and helium (He) are inert gases, having no effect on the metallurgical processes during welding [41]. It shows the effect of shielding gas on the weld penetration. The penetration is deep in He gas, but the depth decreases with an increase in the gas ratio of Ar to He. The penetration is considerably shallower in $\mathrm{N}_{2}$ gas than in He gas [42]. When the shielding is insufficient the heated titanium surface absorbs gases from the air atmosphere, and additionally, titanium forms brittle carbides, nitrides, and oxides causing hardness increasing and simultaneously reducing the fatigue strength and notch toughness of the welded joint and heat affected zone (HAZ). The groove of the weld also must be perfectly protected by shielding gas. Additionally, any surface impurities can diffuse into the titanium, causing porosity and brittleness. Thus the joint area must be decreased and cleaned precisely $[43,44]$. Both are often used to protect the weld pool from the atmosphere, where Ar is usually the preferred choice because of its lower cost. The composition of the shielding gas affects the heat distribution in the weld and therefore controls the weld shape and the welding speed. The extra heat potential of the He can reduce gas entrapment and thus porosity levels by broadening the weld fusion and penetration [45]. The two-component mixtures of Ar and $\mathrm{He}$ are the most satisfactory choices. They have the effect of being associated with minimum defocusing of the incident laser light. The combinations with not very large amounts of Ar seem to be almost as good as pure helium, not only because they do not significantly increase the defocusing but also because they have the further advantage of being economical in the use of He, thus minimizing costs [46].

To optimize the laser welding process and to ensure the production of high weld quality, it is necessary to understand the influence of shielding gas on the overall properties of weld joints. Thus, the paper deals with the comparison of the properties of weld joints produced under the shielding by different types of gases.

\section{Experimental procedure}

\subsection{Characterization of material}

Commercially pure titanium Grade 2 was used as experimental material. The thickness of the base metal was $2.0 \mathrm{~mm}$. Butt titanium weld joints were produced during laser joining. The weld joints were produced in the Centre of Excellence of 5-axis machining at the
Table 1. Chemical composition of CP Titanium Grade 2 (wt.\%)

\begin{tabular}{cccccc}
\hline $\mathrm{Fe}$ & $\mathrm{O}$ & $\mathrm{N}$ & $\mathrm{C}$ & $\mathrm{H}$ & $\mathrm{Ti}$ \\
\hline$\leq 0.3$ & $\leq 0.25$ & $\leq 0.03$ & $\leq 0.1$ & $\leq 0.0125$ & Balance \\
\hline
\end{tabular}

Table 2. Mechanical properties of CP Titanium Grade 2

\begin{tabular}{cccc}
\hline$R_{\mathrm{m}}(\mathrm{MPa})$ & $\mathrm{R}_{\mathrm{p} 0.2}(\mathrm{MPa})$ & $\mathrm{A}_{50}(\%)$ & $\mathrm{HV}$ \\
\hline 417 & 334 & 15.47 & 174 \\
\hline
\end{tabular}

Faculty of Materials Science and Technology in Trnava. Chemical composition of the base material is given in Table 1, and its mechanical properties are summarized in Table 2.

\subsection{Laser equipment and welding parameters}

The welding experiments were performed with the continuous-wave TruDisk 4002 disk laser with the maximum power of $2.0 \mathrm{~kW}$. The wavelength of laser radiation was $1.03 \mu \mathrm{m}$ and beam quality (BPP) $8 \mathrm{~mm}$ mrad. The laser beam was transported to the BEO D70 focusing optics via laser light cable with the core diameter of $200 \mu \mathrm{m}$. The spot size of the laser beam focused on the surface was also $200 \mu \mathrm{m}$. The focal length was $200 \mathrm{~mm}$. The focusing optics was mounted on the Fanuc M-710iC/50 6-axis robot. To evaluate the influence of the shielding gas on the overall weld properties, different shielding gases were used to protect the weld pool. Ar, He, Ar + 5 vol. $\%$ He (trade name Aluline He5), Ar +30 vol.\% He (trade name Aluline He30) were used as shielding gases. Furthermore, the weld joint without shielding was produced. The shielding gas flow rate was kept constant $\left(24 \mathrm{~L} \mathrm{~min}^{-1}\right)$. Weld bead and weld root were protected during laser beam welding. The remaining welding parameters were also constant, i.e., laser power of $1.5 \mathrm{~kW}$, welding speed of $50 \mathrm{~mm} \mathrm{~s}^{-1}$ and focal position of $0 \mathrm{~mm}$ were used. The weld joints were manufactured in the continuous-wave mode. The parameters of welding are given in Table 3 .

\subsection{Preparation of the weld joints}

Following the metallographic preparation of the cross sections of the weld joints, the specimens were etched with Kroll's reagent (chemical composition: $6 \mathrm{~mL} \mathrm{HNO}_{3}+2 \mathrm{~mL} \mathrm{HF}+92 \mathrm{~mL}$ distilled $\mathrm{H}_{2} \mathrm{O}$ ). The macrostructure and microstructure were analysed by light microscopy (NEOPHOT 32 light microscope). JEOL $7600 \mathrm{~F}$ scanning electron microscope was used for the study of the HAZ-weld metal interface in more 
Ta ble 3. Laser welding parameters

\begin{tabular}{|c|c|c|c|c|c|}
\hline No. & $\begin{array}{l}\text { Laser power } \\
\qquad(\mathrm{kW})\end{array}$ & $\begin{array}{l}\text { Welding } \\
\text { speed } \\
\left(\mathrm{mm} \mathrm{s}^{-1}\right)\end{array}$ & $\begin{array}{c}\text { Type of } \\
\text { shielding gas }\end{array}$ & $\begin{array}{c}\text { Shielding gas } \\
\text { flow rate } \\
\left(\mathrm{L} \mathrm{min}^{-1}\right)\end{array}$ & $\begin{array}{l}\text { Focusing } \\
\text { (mm) }\end{array}$ \\
\hline 1 & 1.5 & 50 & $\mathrm{Ar}+30 \% \mathrm{He}$ & 24 & 0 \\
\hline 2 & 1.5 & 50 & $\mathrm{Ar}+5 \% \mathrm{He}$ & 24 & 0 \\
\hline 3 & 1.5 & 50 & $\mathrm{He}$ & 24 & 0 \\
\hline 4 & 1.5 & 50 & $\mathrm{Ar}$ & 24 & 0 \\
\hline 5 & 1.5 & 50 & No shielding & 0 & 0 \\
\hline
\end{tabular}
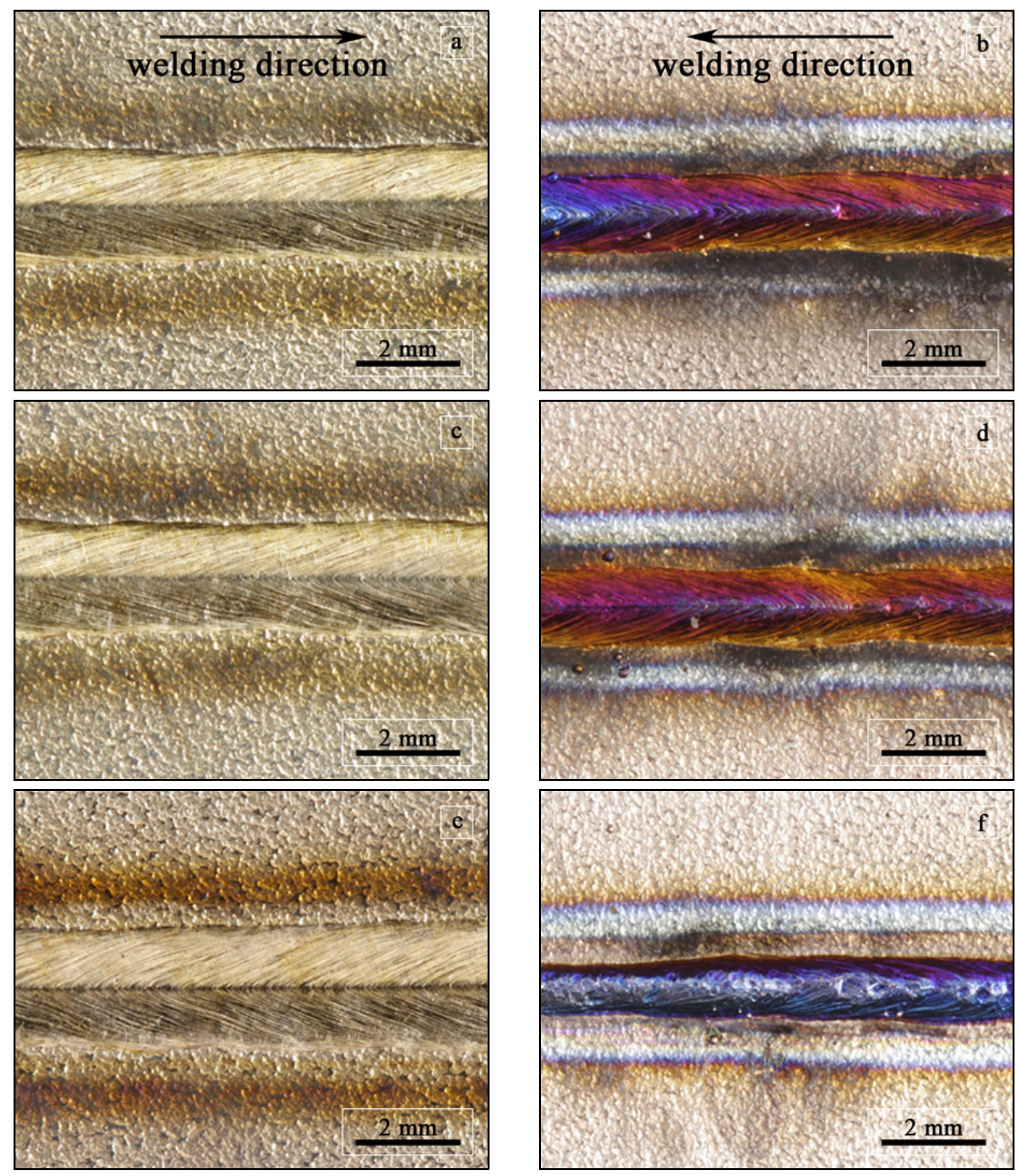

Fig. 1a-f. Appearance of (a) weld bead and (b) weld root of Aluline He30-shielded weld joint, (c) weld bead and (d) weld root of Aluline He5-shielded weld joint, (e) weld bead and (f) weld root of He-shielded weld joint. 

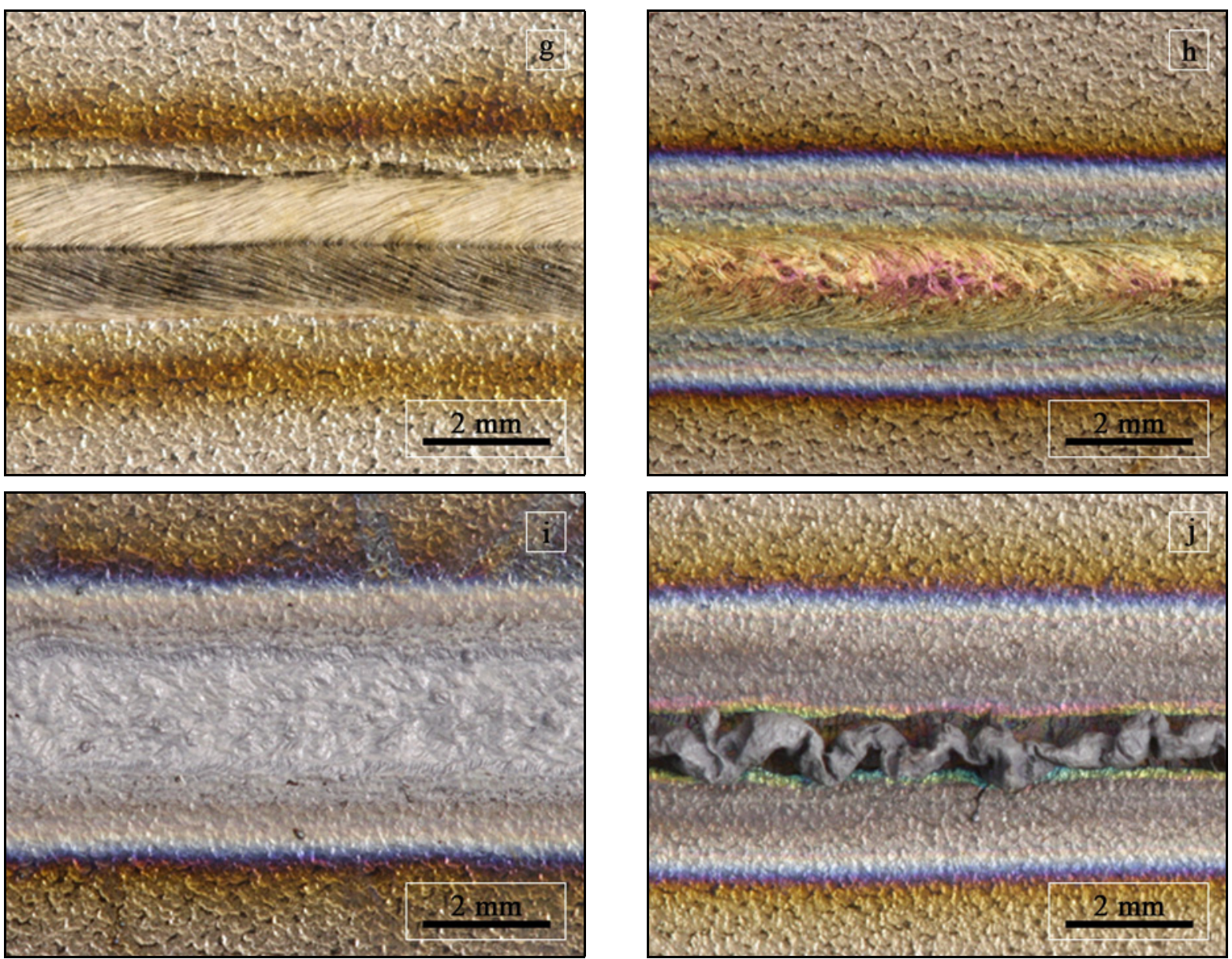

Fig. 1g-j. Appearance of $(\mathrm{g})$ weld bead and $(\mathrm{h})$ weld root of Ar-shielded weld joint, (i) weld bead and (j) weld root of unshielded weld joint.

detail. Zeiss Metrotom 1500 computed tomographybased coordinate measuring machine was used to identify the porosity present in the laser weld joints and its location within the welds. Computed tomography (CT) was capable of measuring the size, distribution, and total volume of the porosity. Weld joints with a length of $100 \mathrm{~mm}$ were subjected to the CT measurements. The parameters of CT were as follows: tube voltage was $225 \mathrm{kV}$, tube power was $500 \mathrm{~W}$, tube type was open X-ray technology, source-detector distance was $440 \mathrm{~mm}$. Measuring a range of the Metrotom 1500 machine is up to $350 \mathrm{~mm} \times 300 \mathrm{~mm}$. Flat-panel detector was used (number of pixels $2048 \times 2048$, pixel size $200 \mu \mathrm{m} \times 200 \mu \mathrm{m})$. Maximum spatial resolution at $10 \%$ modulation transfer is $4.0 \mathrm{~lm}\left(125 \mu \mathrm{p} \mathrm{mm} \mathrm{m}^{-1}\right)$. The enclosure material is lead. Furthermore, the fracture surfaces after the tensile testing were studied by SEM. Vickers microhardness measurements were taken on the Buehler IndentaMet 1100 microhardness tester. The measurement condition was as follows: load $100 \mathrm{~g}$ acting during $10 \mathrm{~s}$. The distance between the indents was $300 \mu \mathrm{m}$ in the weld metal, and HAZ was $200 \mathrm{~lm}$. The tensile strength of the welds was evaluated at room temperature using the LabTest 5.250
Sp1 tensile testing machine (max. load force $250 \mathrm{kN}$ ) of LABORTECH Company at a crosshead speed of $5 \mathrm{~mm} \mathrm{~s}^{-1}$

\section{Results}

\subsection{Weld joints appearance}

The appearance of weld beads and roots of the produced titanium Grade 2 weld joints is given in Figs. 1a-j. Welding direction is marked by the white arrow. The weld joint bead and root produced with laser power of $1.5 \mathrm{~kW}$, welding speed of $50 \mathrm{~mm} \mathrm{~s}^{-1}$ and focal position of $0 \mathrm{~mm}$ is given in Figs. 1a,b. Argon +30 vol. $\%$ He (Aluline He30) was used as shielding gas with the flow rate of $24 \mathrm{~L} \mathrm{~min}^{-1}$. The weld bead was regular but without the presence of spatter. The weld root is also regular from the width point of view, but it is oxidized. Further weld joints were produced with different shielding gases to evaluate their effect on weld joint properties. The further weld joint given in Figs. 1c,d was produced with the same welding parameters, except the type of shielding gas. Aluline He5 

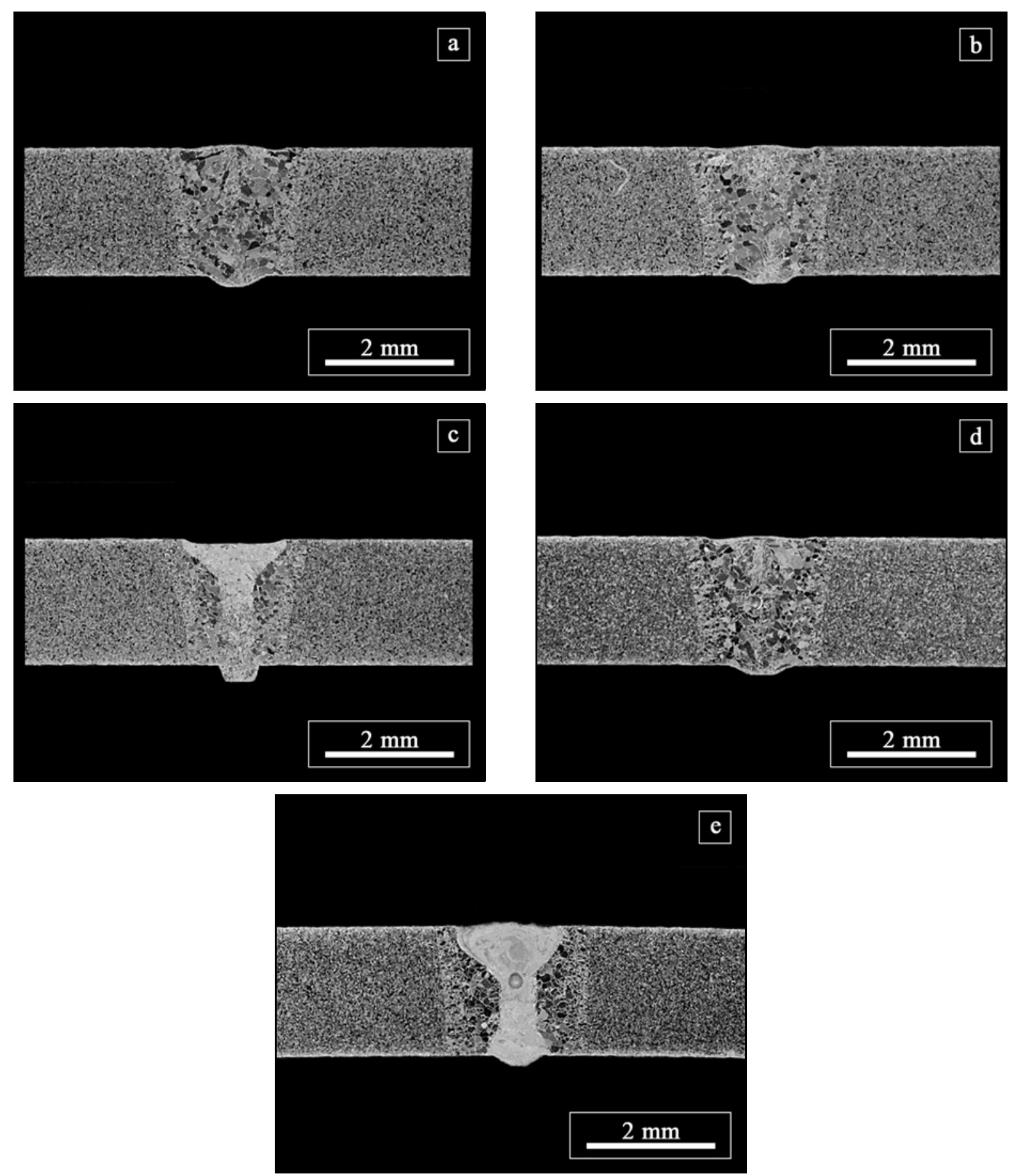

Fig. 2. Cross sections of weld joints produced in various shielding gases, namely (a) Aluline He30 mixture, (b) Aluline He5 mixture, (c) He, (d) Ar, and (e) without shielding.

gas mixture with the composition of $\mathrm{Ar}+5$ vol. $\% \mathrm{He}$ was used as shielding gas in such a case. It is evident that the weld joint width is similar to the previously analysed weld joint. In this case, the weld root was oxidized, too. Figures 1e,f show the weld joint produced with pure He (purity 4.6) as a shielding gas. Weld bead is not smooth and regular, while the weld root is characterized by irregular width. Welding in the $\mathrm{He}$ shielding atmosphere resulted in the production of the narrower weld joint. When argon (purity 4.6) was used as shielding gas during the production of weld joint given in Figs. 1g,h, it became wider in comparison with welding in pure He shielding gas. The weld bead was smooth and regular, while the weld root was oxidized. Finally, weld joint produced without shielding atmosphere is given in Figs. 1i,j. As it could be seen from the weld appearance, weld joint is oxidized, gray coloured. Weld sagging was observed in this case. 


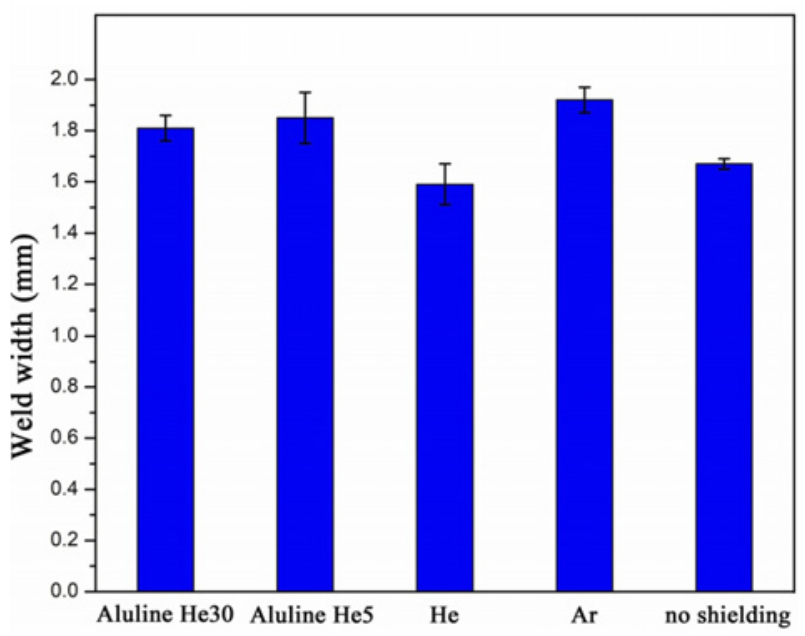

Fig. 3. Weld width of the weld joints for different shielding gases used in the present study

Cross sections of weld joints produced in various shielding gases are given in Fig. 2. The surface of weld metal produced in Aluline He30 shielding gas (Fig. 2a) is almost uniform with the base material, while the weld root is not uniform with the base material. Excessive penetration was observed in this case $(0.17 \mathrm{~mm})$. The weld width is $1.78 \mathrm{~mm}$, and the weld root width is $0.93 \mathrm{~mm}$. The application of Aluline He5 gas mixture (Fig. 2b) resulted in a similar weld width. The measured weld width was $1.85 \mathrm{~mm}$, and the weld root width was $0.98 \mathrm{~mm}$. The weld metal of weld produced in $\mathrm{He}$ is sagging (Fig. 2c). Excessive penetration was also observed in this case $(0.25 \mathrm{~mm})$. The weld width dropped to $1.59 \mathrm{~mm}$ and weld root width to $0.64 \mathrm{~mm}$. The application of pure argon (Fig. 2d) increased weld width. The weld width was $1.92 \mathrm{~mm}$, and the weld root was $1.04 \mathrm{~mm}$ wide. Weld bead is almost uniform with the base material, while the excessive penetration was observed in the weld root produced without shielding atmosphere (Fig. 2e). The weld width was $1.67 \mathrm{~mm}$, and the weld root width was $0.88 \mathrm{~mm}$. Furthermore, severe porosity was observed in the weld metal.

Hot cracking was not observed in weld joints produced in different shielding gases. The surface preparation reduces the hydrogen sources being responsible for microporosity generation and produces a noticeable suppression of porosity [47].

The influence of shielding gas on the weld width is given in Fig. 3. The weld width was measured at three cross sections for each weld joint.

As it arises from the results, the narrowest was the weld joint produced in $\mathrm{He}$ as shielding atmosphere. On the contrary, the widest weld joint was produced when Ar was used as shielding gas. The addition of the He to the gas mixture resulted in a slight drop in the dimensions in comparison with welding in pure He. When arc welding is used, for the $\mathrm{Ar}+\mathrm{He}$ shield- ing gas mixtures, the arc voltage has to be increased with the increase in He content. It is attributed to the higher ionization potential of $\mathrm{He}$ in comparison with Ar. The welding arc becomes more powerful, and more heat is transferred to the workpiece. A larger fusion area is created [48]. In laser welding, we observed different situations. He-shielded weld joints possessed smaller width in comparison with Ar-shielded welds. This is attributed to the fact that the high ionization energy makes it harder for He to ignite into plasma on its own. In this case, the laser beam was not defocused on the plasma formed above the metal surface. So, the energy density is higher, i.e., the laser beam is concentrated onto a small spot, resulting in the production of the narrow and deep weld joint.

Furthermore, the low molecular weight of He increases the recombination between metal ions and the plasma electrons, making the plasma cloud less dense or even suppressing it.

On the contrary, Ar becomes ionized quite easily, because it has low ionization energy $(15.8 \mathrm{eV})$ and is more susceptible to forming a plasma. Plasma formed above the metal surface causes defocusing of the incident laser beam. Energy density decreases, and the weld joint becomes shallower. This is in agreement with Katayama et al. who investigated the effect of the defocused distance on the penetration depth of a laser weld. They found that weld beads are generally deepest under the condition of the focal point below the specimen surface, but become shallow at the longer defocused distance. Furthermore, they found that plume is in He only formed by the emission of neutral metal atoms spouting from a keyhole inlet during welding, while in Ar or N2, gas plasma is always or sometimes formed under the nozzle in addition to the plume from the keyhole, respectively [42]. Ahn et al. [45] observed that the width of the weld produced in Ar was slightly greater than of that welded in He with welding speed of $3 \mathrm{~m} \mathrm{~min}^{-1}$, focusing of $0 \mathrm{~mm}$ and laser power of $4.9 \mathrm{~kW}$. The same result was observed when comparing the root width of the mentioned welds.

On the contrary, the weld was wider when He was used as shielding gas in the case of welding speeds of 4 and $5 \mathrm{~m} \mathrm{~min}^{-1}$. Authors explained it that the extra heat potential and higher thermal conductivity of He increased the energy input to the workpiece at higher welding speeds of 4 and $5 \mathrm{~m} \mathrm{~min}^{-1}$ more effectively than Ar. Reisgen et al. [48] observed that weld produced in Ar had shallow penetration. It was due to the instability of the welding process as a result of the plume formation which consisted of the interaction between the material plasma and Ar shielding gas plasma. Ar frequently produced lots of spatter, so it produced a wrong surface appearance for a weld bead. However, the weld produced in pure He had a continuous and uniform surface morphology together with a stable welding process and full weld penetration. 

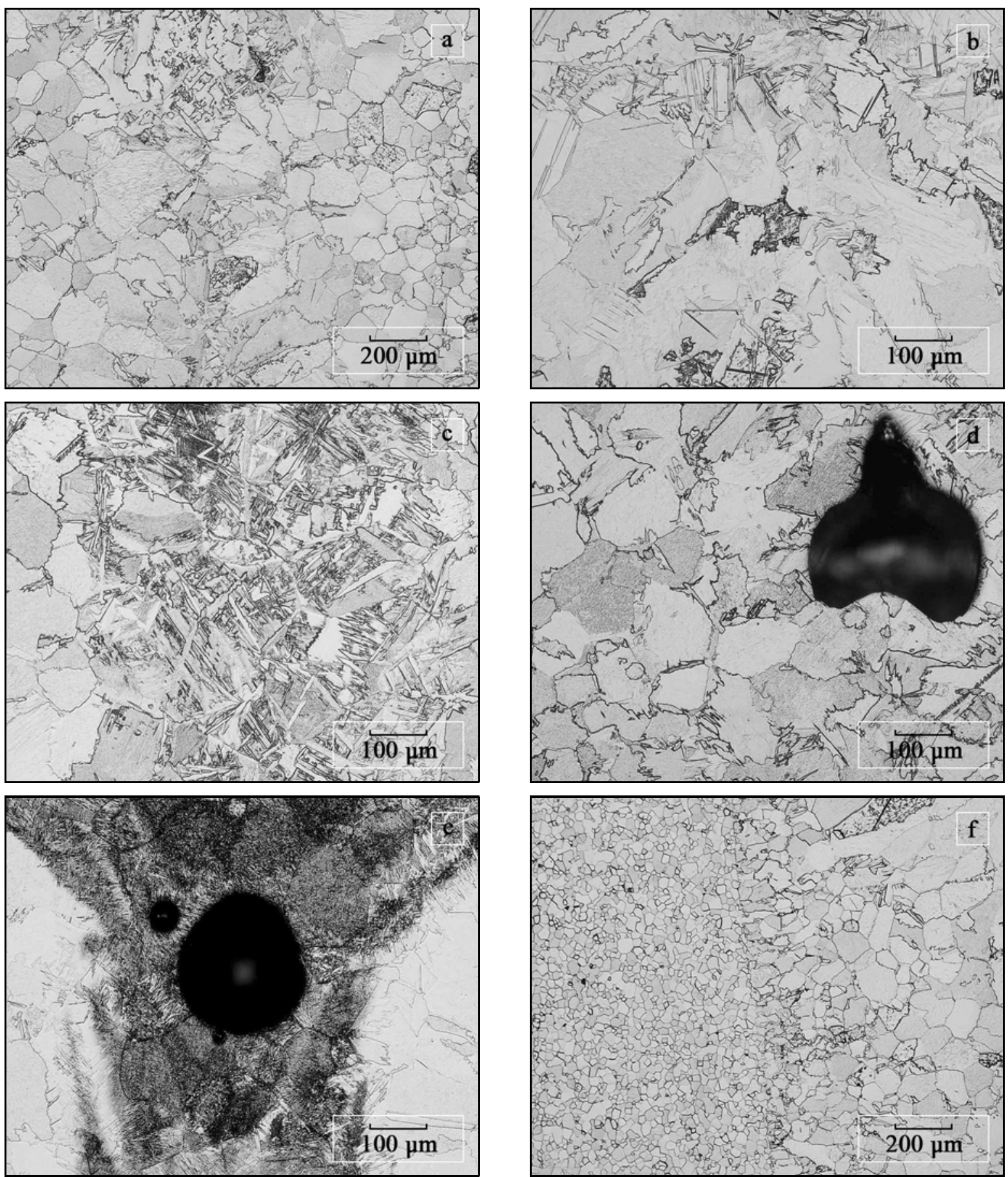

Fig. 4. Microstructure of (a) weld metal-HAZ interface of Aluline He30-shielded weld joint, (b) weld metal of Aluline He5-shielded weld joint, (c) weld metal-HAZ interface of He-shielded weld, (d) weld metal of Ar-shielded weld, (e) weld metal of unshielded weld joint, and (f) base metal-HAZ interface of Aluline He30 shielded weld.

\subsection{Light and electron microscopy}

The microstructure of various zones of Ti Grade 2 weld joints produced in different shielding gases is given in Fig. 4. The base metal-weld metal interface is given in Fig. 4a. This weld joint was produced with the Aluline He30 used as a shielding gas. The microstructure of the heat affected zone of weld shielded by Alu- line He30 mixture has a polyhedral character in particular. In high-temperature heat affected zone, significant grain coarsening can be observed, and most grain boundaries are corrugated. Grains with acicular morphology were rarely observed. The weld metal of the upper part has acicular morphology. In the middle and root part of the weld joint, the weld metal is formed by columnar grains with a preferred orientation that 
copies the direction of heat dissipation during welding. The fine needles and twins can be observed in the columnar grains, which could be due to the presence of $\alpha$, martensite in the weld metal. Columnar grains were observed at the fusion boundary. The grains grew in the direction normal to the fusion boundary. Through the process of epitaxial growth, the initial columnar grain width of the fusion zone is determined by the size of the base metal grains adjacent to the weld interface. Maximum grain size in the HAZ always occurs along with the weld interface, because the peak HAZ temperature increases with decreasing the distance from the weld interface [49]. The microstructure of $\mathrm{HAZ}$ was polyedric. It is evident that bigger grains in HAZ are associated with a low cooling rate. When cold worked alloy is welded, as in our case, the HAZ experiences both recrystallization and grain growth. The hardness and strength properties of recrystallized HAZ lose the benefits derived by cold working and the weld joint strength approaches that of an annealed alloy. As it arises from the microstructure, directional as-rolled grains disappeared in the HAZ due to mentioned recrystallization and grain growth processes [49]. In Fig. 4b is given weld metal that was produced with the Aluline He5 used as a shielding gas. In the weld metal microstructure, needles and twins propagating across the grains can be observed, which may be due to the presence of a martensitic structure in addition to corrugated polyhedral grains. The microstructure of the weld joint produced with He 4.6 is given in Fig. 4c. It can be seen that the weld metal has acicular morphology and consists mainly of $\alpha^{\prime}$ martensite and in the HAZ there are large polyhedral titanium grains. Attar et al. found that the acicular martensitic structure in the weld metal can be attributed to very rapid heating of the sample at high temperatures with its subsequent rapid cooling $10^{3}-10^{8} \mathrm{~K} \mathrm{~s}^{-1}$ [50]. In Fig. 4d is given weld metal that was produced with the Ar 4.6 used as a shielding gas. At the root of the weld joint, a $220 \mu \mathrm{m}$ pore was captured which probably did not escape due to the fast cooling of the weld metal. Also, the flow rate of $24 \mathrm{~L} \mathrm{~min}^{-1}$ is insufficient to protect the melt pool due to the high affinity of titanium to $\mathrm{O}, \mathrm{H}$, and $\mathrm{N}$. The microstructure consists mainly of polyhedral grains with a mild texture and markedly corrugated grain boundaries. They are rarely very small grains with acicular or needle morphology. Li et al. have achieved similar results when using pure Ar. Polyhedral grains and fine acicular structure are present in the weld metal microstructure [18]. In Fig. 4e is given weld metal that was produced without the use of shielding gas. The microstructure shows the fine acicular martensitic structure in the weld metal and the coarse grain in the heat affected zone. Li et al. have achieved the same weld metal morphology. They found that the acicular structure was the result of rapid $\beta$-phase cooling from the temperatures above the $890^{\circ} \mathrm{C} \beta$ transus temperature, slower cooling resulted in grain coarsening [51]. Pores are present in the area of the weld metal. The largest pore was $250 \mu \mathrm{m}$ in diameter. Due to the lack of protection of the melt pool, the weld metal was contaminated by elements from the surrounding atmosphere, which caused the porosity of the weld metal. The formation of the martensitic structure in the weld metal was caused by the rapid cooling of the molten metal. In the HAZ, the grain was coarsened due to slow heat removal. No cracks were observed in the weld metal or the heat affected zone. Figure $4 \mathrm{f}$ documents the microstructure of the HAZ-BM interface (Aluline He 5). The microstructure of the base material has a polyhedral character and is fine-grained with a slight heterogeneity in grain size that ranges from 10 to $60 \mu \mathrm{m}$. In the heat affected zone - base material interface, grain refinement is observed. The microstructure has a polyhedral character, and the corrugation of grain boundaries is documented. The grain size increased with increasing temperature. Grain sizes ranged from 100 to $300 \mu \mathrm{m}$ in high temperature HAZ. In some parts of the heat-affected zone, grains with acicular morphology were sporadically observed. There were no cracks or pores in both the HAZ and fusion boundaries.

Microstructures of weld joints obtained from an electron microscope are given in Fig. 5. Weld metal formed by titanium polyhedral grains in the presence of needles and twins across the grains in Figs. 5a,b documents the transition region from the heat-affected zone to the base material, while in the HAZ large coarsened polyhedral grains are caused by slow cooling. When the base material is cold rolled, recrystallization and grain growth occur in HAZ. The hardness and strength properties of the recrystallized HAZ lose the benefits of cold rolling, and the weld strength is close to the strength of the annealed alloy. As evidenced by the microstructure in HAZ, the direction of the rolled grains dissipated as a result of the recrystallization and grain growth processes [49]. The weld metal microstructure consists mainly of $\alpha$-titanium solid solution matrix. The last figure documents the base material of Grade 2 titanium, which is made up of polyhedral grains with an average size of $50 \mu \mathrm{m}$.

\subsection{TEM analysis}

Using the TEM analysis, it was found that the microstructure of the base material had a polyhedral character and the matrix contained the $\alpha$-phase (i.e., a solid solution of alloying elements in $\alpha$-titanium). In the base material, a slight heterogeneity of the dislocations density was observed. Grains with a relatively low density of dislocations and, on the other hand, grains with a higher density of dislocations were observed, too. Very small polyhedral grains with a minimum density of dislocations were identified by electron 

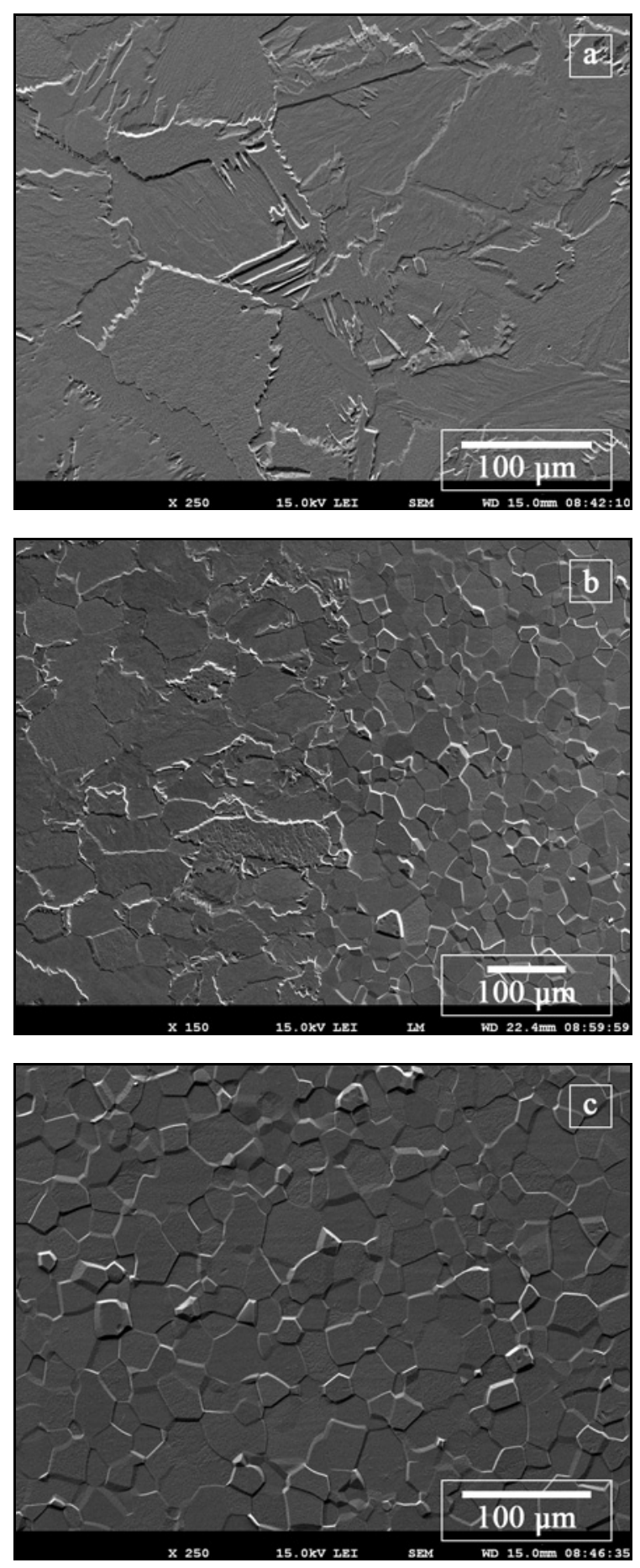

Fig. 5. The microstructure of Aluline He30 shielded weld joint: a) weld metal, (b) HAZ-BM, and (c) base metal.

diffraction as $\beta$-phase (i.e., a solid solution of alloying elements in $\beta$-titanium) (Fig. 6, Table 4). In most polyhedral grains, platelet formations with a predominant orientation in the extrusion or small particles of regular shape were observed. Based on TEM observation results, it can be assumed that they are coherent clusters of alloying elements (the initial precipitation
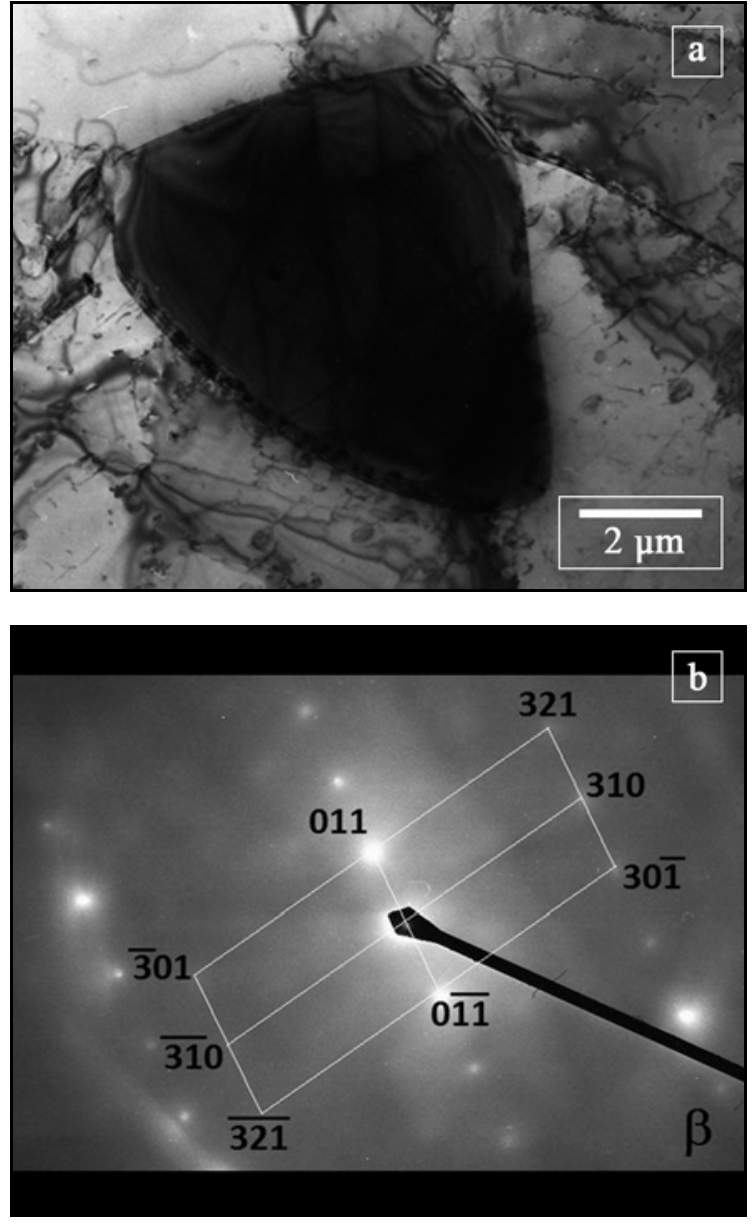

Fig. 6. (a) Detailed view of small polyedric grain with minimum dislocation density and (b) diffraction spectra.

stage). Small particles of regular shape can be a perpendicular cross-section to the platelets. From the nature of the diffraction spectra and the dark field imaging, it can be assumed that these clusters are preferably precipitated in habit planes of the type $<100>_{\alpha}$ or $<002>_{\alpha}$. These planes are mutually perpendicular in the hexagonal close-packed lattice (hcp), and therefore it is possible to assume that in the case of small particles of regular shape, it is a perpendicular section of the plate-like clusters.

Figure 7 is a view of the weld metal microstructure observed by TEM on thin films. The microstructure lost its polyhedral character, and the grains gained in particular acicular morphology, the grain boundaries were without the presence of secondary precipitates, and in most grains, an increased density of dislocations was observed compared to the base material. Eventually, areas with very fine polyhedral grains were observed. Unlike the base material, platelets were observed in the weld metal, but an increased content of dislocation loops was observed in the matrix, which may result from the condensation of vacancies or clus- 
Table 4. Evaluation of diffraction spectra

\begin{tabular}{|c|c|c|c|}
\hline \multicolumn{2}{|c|}{ Solving of diffraction spectra } & \multicolumn{2}{|c|}{ Tabular values for $\beta$-phase } \\
\hline No. & $d_{\mathrm{hkl}}\left(10^{-10} \mathrm{~m}\right)$ & $d_{\mathrm{hkl}}\left(10^{-10} \mathrm{~m}\right)$ & $(\mathrm{h} \mathrm{k} \mathrm{l})$ \\
\hline 1. & 2.40 & 2.33 & $\left(\begin{array}{lll}0 & 1 & 1\end{array}\right)$ \\
\hline 2. & 1.08 & 1.05 & $\left(\begin{array}{lll}3 & 1 & 0\end{array}\right)$ \\
\hline 3. & 0.92 & 0.88 & $\left(\begin{array}{lll}3 & 2 & 1\end{array}\right)$ \\
\hline 4. & 1.08 & 1.05 & $(30 \overline{1})$ \\
\hline$\varphi_{1 / 2}$ & $78^{\circ}$ & $\varphi_{011 / 310}$ & $77.1^{\circ}$ \\
\hline
\end{tabular}

Table 5. Evaluation of diffraction spectra

\begin{tabular}{|c|c|c|c|}
\hline \multicolumn{2}{|c|}{ Solving of diffraction spectra } & \multicolumn{2}{|c|}{ Tabular values for $\alpha$-phase } \\
\hline No. & $d_{\mathrm{hkl}}\left(10^{-10} \mathrm{~m}\right)$ & $d_{\mathrm{hkl}}\left(10^{-10} \mathrm{~m}\right)$ & $(\mathrm{h} \mathrm{k} \mathrm{l})$ \\
\hline 1. & 2.61 & 2.55 & $\left(\begin{array}{lll}0 & 1 & 0\end{array}\right)$ \\
\hline 2. & 2.30 & 2.24 & $\left(\begin{array}{lll}1 & 0 & 1\end{array}\right)$ \\
\hline 3. & 1.49 & 1.41 & $\left(\begin{array}{lll}1 & 1 & 1\end{array}\right)$ \\
\hline 4. & 2.30 & 2.24 & $(11 \overline{1})$ \\
\hline$\varphi_{1 / 2}$ & $64^{\circ}$ & $\varphi_{010 / 101}$ & $63.9^{\circ}$ \\
\hline
\end{tabular}

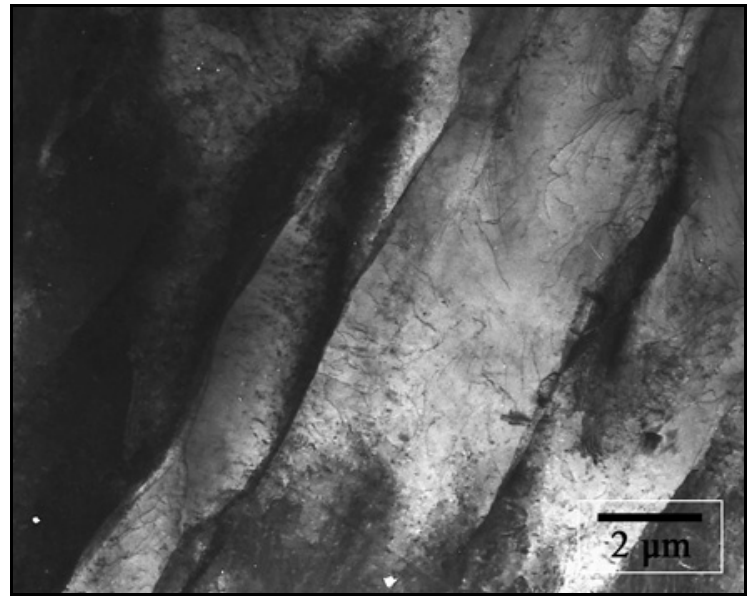

Fig. 7. The acicular character of the microstructure with grain boundaries without the presence of secondary precipitates.

ters of interstitial atoms (Fig. 8, Table 5).

1. The acicular grains of $\alpha$-phase were observed in the weld metal. Areas, where the weld metal has a fine-grained polyhedral structure, were observed,

2. plate-like cluster formation was observed only slightly in the weld metal, but an increased density of dislocation loops was observed as well as an increased density of dislocations in comparison to the base material.

\subsection{Computed tomography}

The sphericity $\Psi$ of a pore was calculated. The sphericity of a pore is given by the ratio of the surface
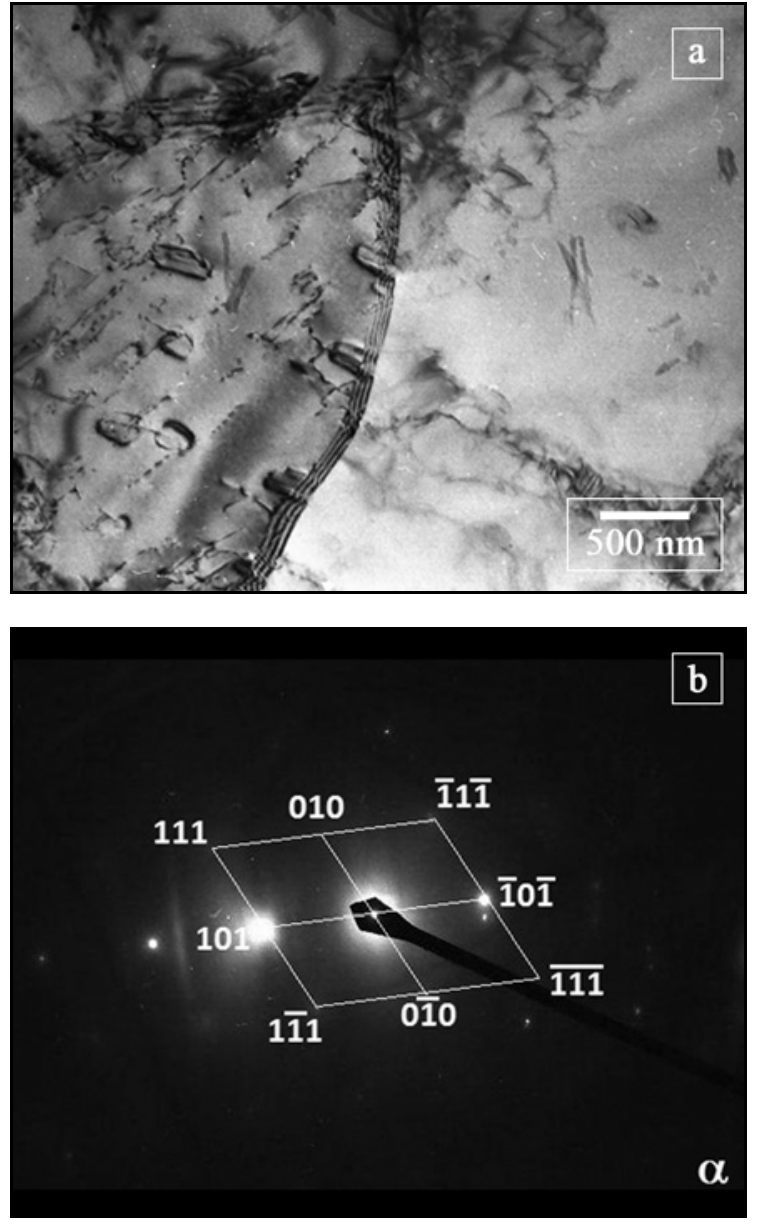

Fig. 8. (a) Detail of dislocation loops in the matrix and (b) diffraction spectra of the matrix 
Table 6. Dimensions of pores observed in the weld joints produced under the Aluline He30 shielding atmosphere

\begin{tabular}{ccccc}
\hline $\begin{array}{c}\text { Radius } \\
(\mathrm{mm})\end{array}$ & $\begin{array}{c}\text { Diameter } \\
(\mathrm{mm})\end{array}$ & $\begin{array}{c}\text { Volume } \\
\left(\mathrm{mm}^{3}\right)\end{array}$ & $\begin{array}{c}\text { Surface } \\
\left(\mathrm{mm}^{2}\right)\end{array}$ & Sphericity \\
\hline 0.32 & 0.64 & 0.04 & 0.90 & 0.62 \\
0.27 & 0.54 & 0.04 & 0.82 & 0.68 \\
0.14 & 0.29 & 0.01 & 0.33 & 0.68 \\
0.27 & 0.54 & 0.02 & 0.55 & 0.64 \\
0.14 & 0.29 & 0.01 & 0.33 & 0.68 \\
\hline
\end{tabular}

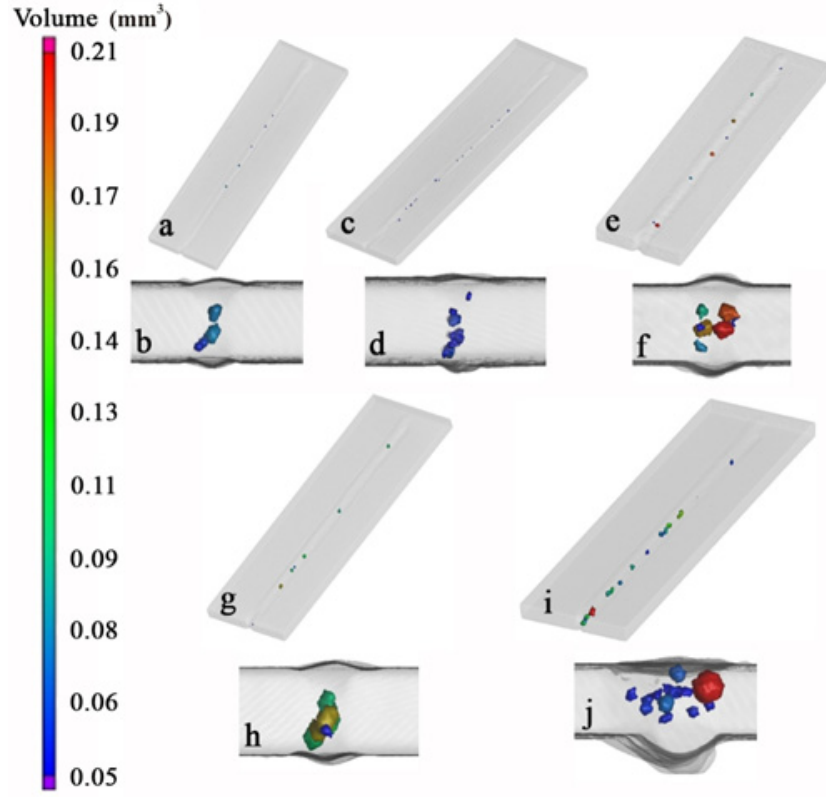

Fig. 9. 3D renderings of the locations of the pores present in Ti Grade 2 weld produced when: (a) and (b) Aluline He30 was used as shielding gas; (c) and (d) Aluline He5 mixture was used for shielding; (e) and (f) He was used as shielding gas; (g) and (h) Ar was used for shielding; (i) and $(\mathrm{j})$ no shielding gas.

area of a sphere (with a volume equal to the pore volume) to that of the pore:

$$
\Psi=\frac{A_{\mathrm{S}}}{A_{\mathrm{P}}}=\frac{\pi^{\frac{1}{3}}\left(6 V_{\mathrm{P}}\right)^{\frac{2}{3}}}{A_{\mathrm{P}}},
$$

where $A_{\mathrm{S}}$ and $A_{\mathrm{P}}$ refer to the surface area of the sphere and pore, respectively, and $V_{\mathrm{P}}$ is the pore volume. Sphericity measures the departure of shape from perfectly spherical $(\Psi=1)$ and measures the extent of deformation for a given pore. The smaller the sphericity value, the more irregular the shape of the pores [52]. Torkamany et al. [53] showed that weld porosity was formed in the pulsed laser welded joints of pure Ti.

Figures 9a,b show the 3D renderings of the locations of the pores present in Ti Grade 2 weld produced when pure Aluline He30 was used as a shielding gas.
The diameter of the largest pore was $0.64 \mathrm{~mm}$, and the volume of porosity was $0.12 \mathrm{~mm}^{3}$, which represents only $0.03 \%$. Porosity was measured 3 times for each weld joint, and an average value was calculated.

Calculated sphericities $\Psi$ of pores present in Aluline He30 shielded weld joint ranged from 0.62 to 0.68 . The results of $\mathrm{CT}$ of weld joint produced under the Aluline He30 shielding atmosphere are given in Table 6 .

Figures $9 \mathrm{c}, \mathrm{d}$ show the $3 \mathrm{D}$ renderings of the locations of the pores present in Ti Grade 2 weld produced when pure Aluline He5 was used as a shielding gas. The amount of porosity increased in comparison to previous weld joints. The diameter of the largest pore was $0.77 \mathrm{~mm}$, and volume of porosity was $0.29 \mathrm{~mm}^{3}$, which represents only $0.1 \%$. Calculated sphericities $\Psi$ of pores present in Aluline $\mathrm{He} 5$ shielded weld joint ranged from 0.62 to 0.99 . The results of $\mathrm{CT}$ of weld joint produced under the Aluline He5 shielding atmosphere are given in Table 7.

Figures $9 \mathrm{e}, \mathrm{f}$ show the $3 \mathrm{D}$ renderings of the locations of the pores present in Ti Grade 2 weld produced when pure He was used as a shielding gas. The amount of porosity increased in comparison to previous weld joints. The porosity was concentrated below the mid-thickness of the weld joint. In this case, the largest subsurface pore was observed with the diameter of $0.89 \mathrm{~mm}$, and volume of porosity was $0.47 \mathrm{~mm}^{3}$, which represents only $0.21 \%$. Calculated sphericities $\Psi$ of pores present in He shielded weld joint ranged from 0.48 to 0.89 . The results of CT of weld joint produced under the He 4.6 shielding atmosphere are given in Table 8.

Figures $9 \mathrm{~g}$, h show the $3 \mathrm{D}$ renderings of the locations of the pores present in Ti Grade 2 weld produced when pure Ar was used as a shielding gas. The diameter of the largest pore was $0.97 \mathrm{~mm}$, and volume of porosity was $0.81 \mathrm{~mm}^{3}$, which represents only $0.32 \%$. Takayama et al. studied the formation of porosity, and they found that the increase in the Ar shielding gas flow rate resulted in a decrease in the porosity [54]. Calculated sphericities $\Psi$ of pores present in pure $\mathrm{Ar}$ shielded weld joint ranged from 0.58 to 0.99 . The results of CT of weld joint produced under the pure Ar shielding atmosphere are given in Table 9 .

The shielding effect of the mentioned gas mix- 
Table 7. Dimensions of pores observed in the weld joints produced under the Aluline He5 shielding atmosphere

\begin{tabular}{|c|c|c|c|c|}
\hline $\begin{array}{c}\text { Radius } \\
(\mathrm{mm})\end{array}$ & $\begin{array}{l}\text { Diameter } \\
(\mathrm{mm})\end{array}$ & $\begin{array}{c}\text { Volume } \\
\left(\mathrm{mm}^{3}\right)\end{array}$ & $\begin{array}{r}\text { Surface } \\
\left(\mathrm{mm}^{2}\right)\end{array}$ & Sphericity \\
\hline 0.22 & 0.77 & 0.03 & 0.75 & 0.62 \\
\hline 0.20 & 0.41 & 0.02 & 0.56 & 0.63 \\
\hline 0.18 & 0.47 & 0.03 & 0.53 & 0.88 \\
\hline 0.24 & 0.48 & 0.02 & 0.46 & 0.77 \\
\hline 0.14 & 0.29 & 0.03 & 0.50 & 0.93 \\
\hline 0.18 & 0.37 & 0.01 & 0.27 & 0.83 \\
\hline 0.14 & 0.29 & 0.02 & 0.39 & 0.91 \\
\hline 0.13 & 0.26 & 0.02 & 0.37 & 0.96 \\
\hline 0.14 & 0.29 & 0.01 & 0.27 & 0.83 \\
\hline 0.14 & 0.29 & 0.02 & 0.36 & 0.99 \\
\hline 0.14 & 0.29 & 0.03 & 0.49 & 0.95 \\
\hline 0.13 & 0.26 & 0.01 & 0.25 & 0.89 \\
\hline 0.14 & 0.29 & 0.02 & 0.39 & 0.91 \\
\hline 0.13 & 0.26 & 0.02 & 0.38 & 0.93 \\
\hline
\end{tabular}

Table 8. Dimensions of pores observed in the weld joints produced under the He 4.6 shielding atmosphere

\begin{tabular}{ccccc}
\hline $\begin{array}{c}\text { Radius } \\
(\mathrm{mm})\end{array}$ & $\begin{array}{c}\text { Diameter } \\
(\mathrm{mm})\end{array}$ & $\begin{array}{c}\text { Volume } \\
\left(\mathrm{mm}^{3}\right)\end{array}$ & $\begin{array}{c}\text { Surface } \\
\left(\mathrm{mm}^{2}\right)\end{array}$ & Sphericity \\
\hline 0.39 & 0.77 & 0.13 & 1.67 & 0.74 \\
0.35 & 0.70 & 0.09 & 1.53 & 0.63 \\
0.39 & 0.77 & 0.12 & 1.61 & 0.73 \\
0.32 & 0.63 & 0.04 & 0.90 & 0.62 \\
0.20 & 0.40 & 0.01 & 0.46 & 0.48 \\
0.22 & 0.44 & 0.02 & 0.44 & 0.81 \\
0.22 & 0.44 & 0.03 & 0.52 & 0.89 \\
0.37 & 0.74 & 0.03 & 0.79 & 0.59 \\
\hline
\end{tabular}

Table 9. The dimensions of pores observed in the weld joints produced under the Ar 4.6 shielding atmosphere

\begin{tabular}{ccccc}
\hline $\begin{array}{c}\text { Radius } \\
(\mathrm{mm})\end{array}$ & $\begin{array}{c}\text { Diameter } \\
(\mathrm{mm})\end{array}$ & $\begin{array}{c}\text { Volume } \\
\left(\mathrm{mm}^{3}\right)\end{array}$ & $\begin{array}{c}\text { Surface } \\
\left(\mathrm{mm}^{2}\right)\end{array}$ & Sphericity \\
\hline 0.40 & 0.79 & 0.15 & 1.59 & 0.58 \\
0.49 & 0.97 & 0.12 & 2.49 & 0.95 \\
0.43 & 0.87 & 0.15 & 1.26 & 0.99 \\
0.39 & 0.77 & 0.11 & 1.45 & 0.84 \\
0.35 & 0.70 & 0.11 & 1.42 & 0.96 \\
0.27 & 0.54 & 0.08 & 0.90 & 0.94 \\
0.19 & 0.39 & 0.09 & 0.38 & \\
\hline
\end{tabular}

ture was more effective because the overall porosity dropped against pure shielding gases.

Figures $9 \mathrm{i}, \mathrm{j}$ show the $3 \mathrm{D}$ renderings of the locations of the pores present in Ti Grade 2 weld produced when pure Ar was used as a shielding gas. The diameter of the largest pore was $1.28 \mathrm{~mm}$, and the overall porosity increased in comparison to previous weld joints. The volume of porosity was $1.45 \mathrm{~mm}^{3}$, which represents $0.76 \%$. Calculated sphericities $\Psi$ of pores present without shielded weld joint ranged from 0.53 to 0.89 . The results of CT of weld joint produced without shielding atmosphere are given in Table 10.

The shielding effect of the mentioned gas mix- ture was more effective because the overall porosity dropped in comparison to pure shielding gases. Pure Ar and He have different densities to maintain approximately the same shielding effect; the gas flow rate has to be changed. With the increase of $\mathrm{He}$ content in the gas mixture, the shielding gas flow needs to be increased. The higher content of porosity in He shielded weld joint could be associated with not sufficient shielding gas flow rate of $\mathrm{He}$, which was $24 \mathrm{~L} \mathrm{~min}^{-1}$ in our study. For the next research, the flow rate could be increased, which on the contrary increases the overall welding process cost. It was found that porosity formation was reduced when $\mathrm{Ar}+\mathrm{He}$ 
Ta ble 10. Dimensions of pores observed in the weld joints produced without shielding atmosphere

\begin{tabular}{|c|c|c|c|c|}
\hline $\begin{array}{c}\text { Radius } \\
(\mathrm{mm})\end{array}$ & $\begin{array}{l}\text { Diameter } \\
(\mathrm{mm})\end{array}$ & $\begin{array}{r}\text { Volume } \\
\left(\mathrm{mm}^{3}\right)\end{array}$ & $\begin{array}{r}\text { Surface } \\
\left(\mathrm{mm}^{2}\right)\end{array}$ & Sphericity \\
\hline 0.38 & 0.76 & 0.11 & 1.72 & 0.89 \\
\hline 0.45 & 0.9 & 0.12 & 1.83 & 0.64 \\
\hline 0.64 & 1.28 & 0.21 & 3.17 & 0.64 \\
\hline 0.43 & 0.85 & 0.09 & 1.59 & 0.53 \\
\hline 0.59 & 1.17 & 0.15 & 2.43 & 0.61 \\
\hline 0.40 & 0.79 & 0.09 & 1.50 & 0.56 \\
\hline 0.32 & 0.64 & 0.05 & 1.07 & 0.64 \\
\hline 0.37 & 0.75 & 0.08 & 1.42 & 0.61 \\
\hline 0.27 & 0.54 & 0.05 & 0.93 & 0.63 \\
\hline 0.32 & 0.64 & 0.07 & 1.34 & 0.70 \\
\hline 0.37 & 0.74 & 0.06 & 1.18 & 0.61 \\
\hline 0.46 & 0.92 & 0.13 & 2.08 & 0.62 \\
\hline 0.49 & 0.98 & 0.11 & 1.86 & 0.59 \\
\hline 0.35 & 0.69 & 0.06 & 1.18 & 0.59 \\
\hline 0.40 & 0.79 & 0.09 & 1.75 & 0.62 \\
\hline
\end{tabular}

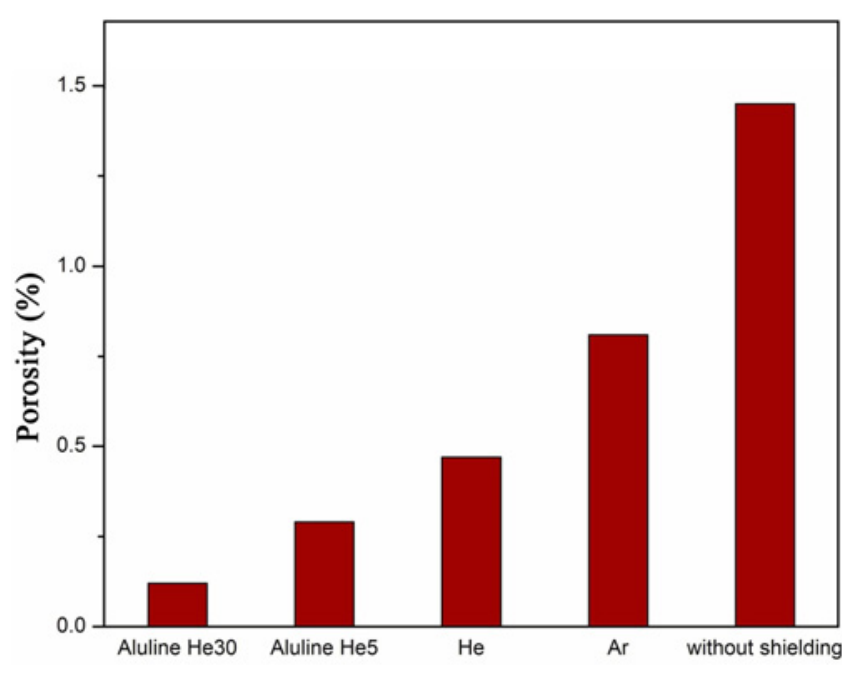

Fig. 10. The porosity of the weld joints for different shielding gases used in the present study.

mixtures were used as the shielding gas instead of pure Ar or He shielding gas. Similar results obtained Takahashi et al. who stated that with Ar shielding gas, the number of pores increased when the beam was focused above the specimen surface, while with He shielding gas it increased when the beam was focused in the weld pool [55]. Panwisawas et al. investigated the influence of welding speed and material thickness on the porosity. They found that the porosity increased with the increase of the material thickness. Also, lower welding speed led to greater porosity level [56]. So, the maximum porosity was in our study $1.45 \%$ if shielding gas was not used (Fig. 10).

There are two types of porosity in the weld metal. Generally, the process induced porosity has an irregular shape with a relatively large size compared with metallurgical porosity. The processing porosity is usually induced by an unstable keyhole during penetration welding. However, for a metallurgical porosity made of hydrogen gas, a smaller diameter can be found ranging from tens to hundred micrometers. If protection of the weld pool is fully effective, hydrogen in the weld pool mainly originates from the surface oxide film [57-61]. Glowacki found that the best combinations are in the range $0 \% \mathrm{Ar}$ and $100 \% \mathrm{He}$ up to $50 \%$ Ar and $50 \%$ He (per unit volume of the gas mixture). The Ar + He gas mixtures with less than about $50 \%$ of He lead to significant defocusing of the incoming laser light in the plume plasma above the laser generated keyhole [46]. The plasma formation is crucial to the welding operation. However, the welding carried out on disk lasers means that this problem is not very serious due to the shorter wavelength of $1.03 \mu \mathrm{m}$. The emitted radiation is less absorbed into the plasma cloud [62]. However, Gao et al. found when the laser power was in their study lower than $5 \mathrm{~kW}$, the laser power absorbed by the plume was no more than $5 \%$ because it was a weakly ionized plasma. At that stage, the plasma shielding effect could be ignored, and the weld penetration depth increased with laser power proportionally. However, when the laser power was higher than $5 \mathrm{~kW}$, the laser power absorbed by laser plume is up to $24 \%$ [63]. Only large pores were detected within the CT measurements.

Further research must be aimed with the computer microtomography, i.e., utilization of reducing pixel size.

Slotwinski et al. observed that some samples have pores not measurable by the X-ray CT that could be seen using a $2.4 \mu \mathrm{m}$ pixel size. There could have been pores several times smaller than this that did not show up in the X-ray CT images [64]. Detectability of smaller pores by $\mu \mathrm{CT}$ could be associated with the 


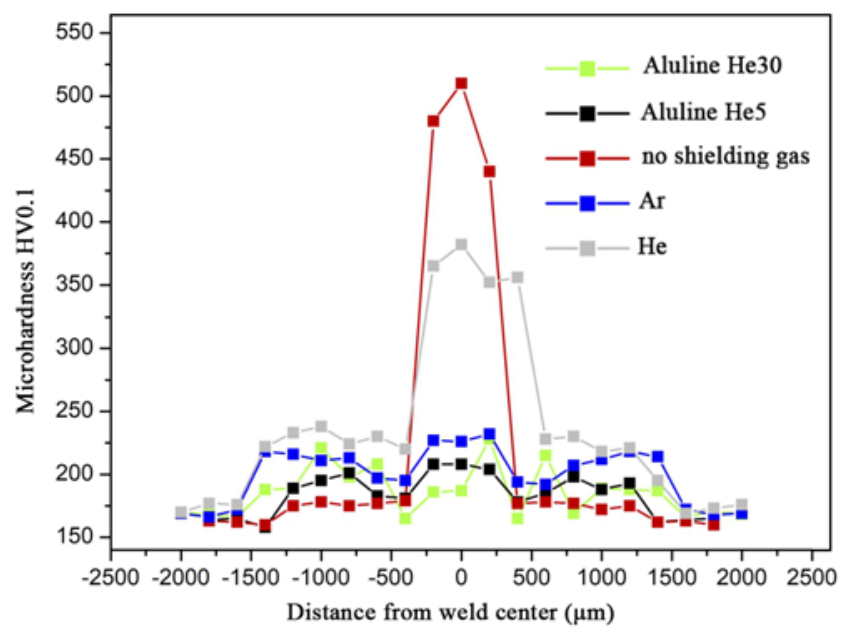

Fig. 11. The course of microhardness for weld joints produced in different shielding gases.

influence of the segmentation algorithms on the porosity detected. Heim et al. found that 'Isodata' detect mostly small pores while ' 0,0 ' would detect the largest pores. "Isodata" was found to be the most powerful algorithm detecting most of the pores regarding pore volume and number [65].

\subsection{Microhardness measurements}

The course of microhardness for weld joints produced in different shielding gases is given in Fig. 11. The microhardness increased from the base metal towards weld metal in all cases. This microhardness increase is associated with the low heat input characterized by laser beam welding. Furthermore, the presence of $\mathrm{Fe}$ in the base metal caused grain refinement in the weld metal and led to an increase in microhardness. Maximum microhardness was in all cases observed in the weld metal. As it follows from measured microhardness values, the influence of shielding gas used for welding is evident. The highest average microhardness was measured in not shielded weld joint. The mentioned weld joint exhibited the highest porosity level and lowest tensile strength from shielded welds. The higher values of microhardness could be attributed to the oxidation of molten metal during welding due to unshielding of the weld pool. The average microhardness of weld metal was 479 HV0.1 in this case.

When shielding gas consisting of the Ar +5 vol. $\%$ He (Aluline He5) was used, the lower average microhardness of weld metal was observed. The value was $206.3 \mathrm{HV} 0.1$. In the case of using the mixture of $\mathrm{Ar}+30$ vol. \% He (Aluline He30) the microhardness dropped to 190.4 HV0.1. The lowest microhardness exhibited the weld joint produced in pure argon. The average microhardness was approximately 227.8 HV0.1. When pure He was used as a shielding gas, the av-

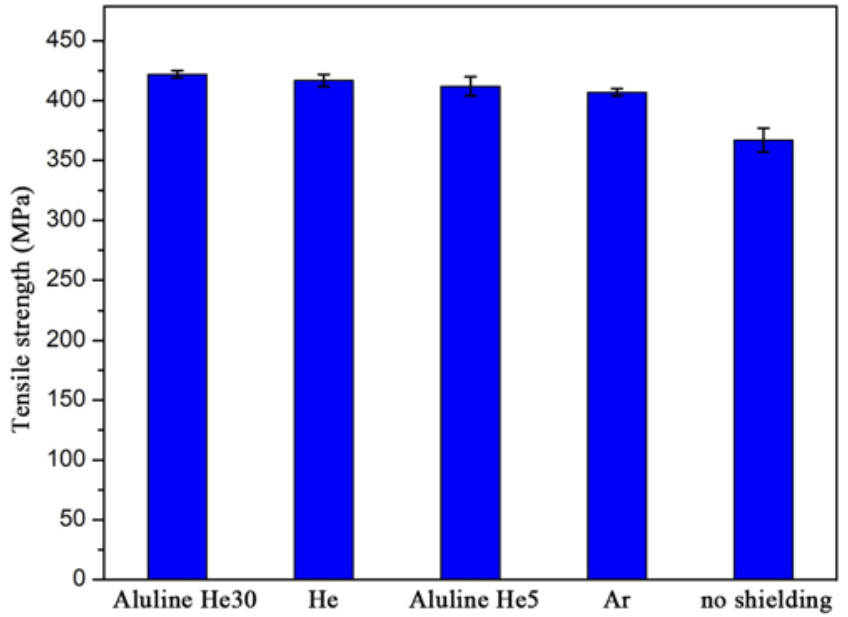

Fig. 12. Tensile strength of the weld joints for different shielding gases used in the present study.

erage microhardness of weld metal increased to 359.4 HV0.1. Similar results achieved Prokić-Cvetković et al. who found that the hardness values for the weld metal in the He shielding gas were somewhat higher, leading to the conclusion that the larger amount of $\mathrm{He}$ in the shielding atmosphere results in the mild increase in hardness [39]. Zinelis investigated the influence of gases on the porosity, microstructure, and mechanical properties. They found out that the highest microhardness was measured when helium was used. Ar, $\mathrm{Kr}, \mathrm{He}$, and Xe were compared. Higher porosity was detected when $\mathrm{He}$ and Ar were used in comparison to $\mathrm{Xe}$ and $\operatorname{Kr}[66]$.

\subsection{Tensile strength}

The dependence of tensile strength on the type of shielding gas is given in Fig. 12. The highest tensile strength was recorded in the case when Aluline He30 gas mixture $\left(R_{\mathrm{m}}=422 \mathrm{MPa}\right)$ was used to protect the weld pool against ambient atmosphere. Lower tensile strength was recorded when Ar was used as shielding gas $\left(R_{\mathrm{m}}=407 \mathrm{MPa}\right)$. The lowest tensile strength, as expected, was observed when the molten pool was unshielded during welding of Ti Grade 2. In this case, fracture occurred in the weld metal. This is associated with a large amount of porosity present in the weld metal. The measured tensile strength was $367 \mathrm{MPa}$. Reisgen et al. observed that the best strength ratio (weld strength/TRIP steel strength) was achieved when $100 \%$ He was used as a shielding gas. Similarly, with our study, the worst strength ratio was produced when the shielding gas was not used [48].

Pores with a mean diameter below $50 \mu \mathrm{m}$ are designated as micropores. Micropores are associated with hydrogen and other common gases in the case of inappropriate weld surfaces preparation. Macro- 

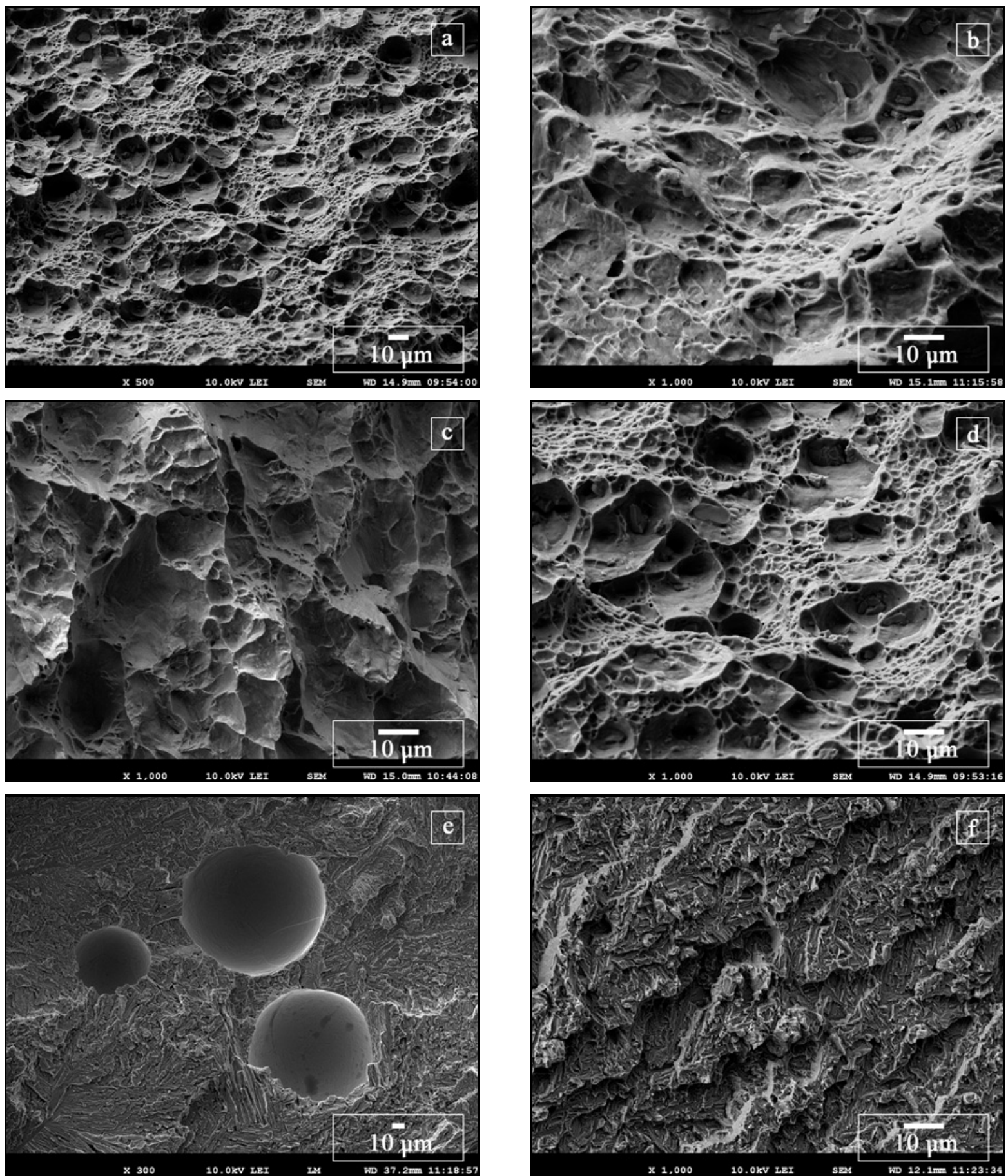

Fig. 13. The fracture surface of (a) Aluline He30 shielded weld joint, (b) Aluline He5 shielded weld joint, (c) He shielded weld joint, (d) Ar shielded weld joint, (e) unshielded weld joint, and (f) higher magnification of unshielded fracture surface.

pores, ranging in size over $300 \mu \mathrm{m}$, seriously affect the mechanical properties and are generally found along the weld bead centre line. Keyhole collapses during welding are a possible reason for their formation [67]. Prokić-Cvetković found in their study that tensile strength of the weld in whole was not influenced by the composition of the shielding atmosphere $[39]$.

\subsection{Fracture surfaces analysis}

Results of the analysis of the fracture surfaces are given in Figs. 13a-f. SEM images of the fracture surface of weld joint produced under the shielding of Aluline He30 and Aluline He5 are documented in Figs. 13a,b. Ductile fracture with characteristic dimples was observed. The use of pure shielding gases Ar 
and He during welding was very similar because no pores were observed on the fracture surfaces. Similarly, ductile fractures with characteristic dimples were observed when He (Fig. 13c) and Ar (Fig. 13d) were used. The fracture was observed in the base metal in the mentioned weld joints. When the shielding gas was not utilized, the porosity was the highest. Pores were observed on the fracture surfaces (Fig. 13e). The fracture was observed in the weld metal.

SEM images of the fracture surface of the unshielded weld joint (Figs. 13e,f) after tensile testing shows the brittle fracture. Specimen fractured in the weld metal. The porosity was the main reason for the cracking in the weld metal. This weld was characterized by the high content of pores decreasing its mechanical properties. Because no shielding was used during welding, gases from the ambient atmosphere were entrapped in the molten metal during solidification. Severe oxidation of weld metal occurred which resulted in the production of the brittle weld. Furthermore, the pores acted as stress concentrators during tensile loading.

\section{Conclusions}

The influence of different shielding gases used during TruDisk 4002 disk laser welding of Ti Grade 2 was investigated. The following can be stated based on the reached results:

- He shielded weld joints were the narrowest ones. On the other hand, Ar shielded weld joints exhibited the largest weld width;

- The acicular grains of $\alpha$-phase were observed in the weld metal. Areas, where the weld metal has a fine-grained polyhedral structure, were found;

- Plate-like clusters formation was observed only slightly in the weld metal, but an increased density of dislocation loops was observed as well as an increased density of dislocations in comparison to the base material;

- The highest tensile strength was recorded in the case when Aluline He30 $\left(R_{\mathrm{m}}=422 \mathrm{MPa}\right)$ mixture was used, the lowest tensile strength, as expected, was observed when the molten pool was not shielded during welding of Ti Grade $2\left(R_{\mathrm{m}}=367 \mathrm{MPa}\right)$;

- The highest average microhardness was measured in unshielded weld joint; the lowest microhardness exhibited the weld joint produced in pure Aluline He30;

- The minimum porosity was recorded in the weld joint produced under the shielding of Aluline He30 mixture; the value was only $0.03 \%$. Contrary, the maximum porosity was $0.56 \%$ in the unshielded weld joint;

- The proper laser welding parameters of Ti Grade 2 are: laser power $P=1.5 \mathrm{~kW}$, welding speed $v=$
$50 \mathrm{~mm} \mathrm{~s}^{-1}$, focal position $f=0 \mathrm{~mm}$ and Aluline He30 mixture with the gas flow rate of $24 \mathrm{~L} \mathrm{~min}^{-1}$.

\section{Acknowledgements}

This work was supported by the VEGA Grants No. 1/0122/16 and 1/0876/15 of the Grant Agency of the Ministry of Education, Science, Research and Sport of the Slovak Republic. The publication is also the result of the project implementation: CE for Development and Application of Advanced Diagnostic Methods in Processing of Metallic and Nonmetallic Materials - APRODIMET, ITMS:26220120048, supported by the Research \& Development Operational Programme funded by the ERDF.

\section{References}

[1] Sahul, M., Sahul, M., Vyskoč, M., Čaplovič, L., Pašák, M.: J. of Mater. Eng. and Perform., 26, 2017, p. 1346. doi:10.1007/s11665-017-2529-6

[2] Zhu, Y., Li, Ch., Zhang, L.: Materials Transactions, 55, 2014, p. 511. doi:10.2320/matertrans.M2013373

[3] Sahoo, S., Bishoiy, B., Mohanty, U., Sahu, J., Bathe, R.: Trans. Indian Inst. Met., 70, 2017, p. 1817. doi:10.1007/s12666-016-0976-7

[4] Fabbro, R. A., Coste, F., Sabatier, L., Billion, J. P.: US Patent, US2004/0099643 A1. 2004.

[5] Ancona, A., Sibillano, T., Lugara, P.M., Gonnella, G., Pascazio, G., Maffione, D.: J. Phys. D: Appl. Phys., 39, 2006, p. 563. doi:10.1088/0022-3727/39/3/022

[6] Squillace, A., Prisco, U., Ciliberto, S., Astarita, A.: Journal of Materials Processing Technology, 212, 2012, p. 427. doi:10.1016/i.jmatprotec.2011.10.005

[7] Vyskoč, M., Sahul, M., Sahul, M.: J. of Mater. Eng. and Perform., 27, 2018, p. 2993. doi:10.1007/s11665-018-3383-x

[8] Schultz, V., Seefeld, T., Vollertsen, F.: Physics Procedia, 56, 2014, p. 545. doi:10.1016/i.phpro.2014.08.037

[9] Wu, A., Song, Z., Nakata, K., Liao, J., Zhou, L.: Mater. Des., 71, 2015, p. 85. doi:10.1016/j.matdes.2014.12.015

[10] Kalaiselvan, K., Elango, A., Nagarajan, N., Mathiyazagan, N.: Int. J. Chem. Nucl. Mater. Metall. Eng., 8, 2014, p. 795. doi:10.5281/zenodo.1093785

[11] Chen, S. H., Li, L. Q., Chen, Y. B., Liu, D. J.: Transactions of Nonferrous Metals Society of China, 20, 2010, p. 64. doi:10.1016/S1003-6326(09)60098-4

[12] Chen, Y. H., Ni, Q., Ke, L. M.: Transactions of Nonferrous Metals Society of China, 22, 2012, p. 299. doi:10.1016/S1003-6326(11)61174-6

[13] Donachie, M. J.: Titanium: A Technical Guide. 2nd Edition. Materials Park, ASM International 2004.

[14] Lütjering, G., Williams, J. C.: Titanium. 2nd Edition. Berlin, Springer 2003.

[15] Pasang, T., Tao, Y., Azizi, M., Kamiya, O., Mizutani, M., Misiolek, W.: MATEC Web of Conferences, 123, 2017, p. 00001. doi:10.1051/matecconf $/ 201712300001$

[16] Auwal, S. T., Ramesh, S., Yusof, F., Manladan, S. M.: Int. J. Adv. Manuf. Technol., 97, 2018, p. 1071. doi:10.1007/s00170-018-2030-x 
[17] Li, C., Muneharua, K., Takao, S., Kouji, H.: Mater. Des., 30, 2009, p. 109. doi:10.1016/j.matdes.2008.04.043

[18] Li, X., Xie, J., Zhou, Y.: J. Mater. Sci., 40, 2005, p. 3437. doi:10.1007/s10853-005-0447-8

[19] Britton, T. B., Liang, H., Dunne, F. P. E., Wilkinson, A. J.: Proc. R. Soc. A, 466, 2010, p. 695. doi:10.1098/rspa.2009.0455

[20] Merson, E., Brydson, R., Brown, A.: J. Phys. Conf. Ser., 126, 2008, p. 012020. doi:10.1088/1742-6596/126/1/012020

[21] Liu, H., Nakata, K., Yamamoto, N., Liao, J.: Science and Technology of Welding and Joining, 16, 2011, p. 581. doi:10.1179/1362171811Y.0000000054

[22] Karpagaraj, A., Sivashanmugam, N.: Materials Science \& Engineering A, 640, 2015, p. 180. doi:10.1016/i.msea.2015.05.056

[23] Gorinin, I. V., Florinsky, J. B., Chechukin, B. B.: The Science, Technology and Application of Titanium. Oxford, Pergamon Press 1968.

[24] Köse, C., Karaca, E.: Journal of Metals, 7, 2017, p. 221. doi:10.3390/met7060221

[25] Gao, X., Zhang, L., Liu, J., Zhang, X.: Materials Science and Engineering A, 559, 2013, p. 14. doi:10.1016/j.msea.2012.06.016

[26] Balasubramanian, T., Balakrishnan, M., Balasubramanian, V., Manickam, M.: Science and Technology of Welding and Joining, 16, 2011, p. 702. doi:10.1179/1362171811Y.0000000062

[27] Murthy, K., Sundaresan, S.: Journal of Materials Science, 33, 1998, p. 817. doi:10.1023/A:1004374703630

[28] Cui, L., Kutusna, M., Simizu, T., Horio, K. F.: Materials and Design, 30, 2009, p. 109. doi:10.1016/j.matdes.2008.04.043

[29] Lathabai, S., Jarvi, B. L., Barton, K. J.: Materials Science and Eng. A, 299, 2001, p. 81. doi:10.1016/S0921-5093(00)01408-8

[30] Akman, E., Demir, A., Canel, T., Sinmazcelik, T.: Journal of Material Processing Technology, 209, 2009, p. 3705. doi:10.1016/j.jmatprotec.2008.08.026

[31] Mitchell, R., Short, A., Pasang, T., Littlefair, G.: Structural Integrity and Failure - SIF. Auckland, University of Auckland 2010.

[32] Kuo, T.-Y., Lin, Y.-D.: Mater. Trans., 48, 2007, p. 219. doi:10.2320/matertrans.48.219

[33] Gaikwad, A., Deore, H., Kotwal, V., Pawar, A., Valli, A.: In: Proceedings of International Conference on Ideas, Impact and Innovation in Mechanical Engineering 2017. Bikaner, Auricle Technologies Pvt. Ltd. 2017, p. 789. ISSN: 2321-8169.

[34] Schneider, A., Avilov, A., Gumenyuk, A., Rethmeier, M.: Phys. Procedia, 2013, 41, p. 4. doi:10.1016/j.phpro.2013.03.045

[35] Tu, J., Paleocrassas, A.: Low-Speed Laser Welding of Aluminium Alloys Using Single-Mode Fiber Lasers. In: Laser Welding. London, IntechOpen Limited 2010. ISBN 978-953-307-129-9.

[36] Heinen, P., Wu, H., Olowinsky, A., Gillner, A.: Phys. Procedia, 56, 2014, p. 554. doi:10.1016/i.phpro.2014.08.043

[37] Campanelli, S., Casalino, G., Mortello, M., Angelastro, A., Ludovico, A.: Procedia CIRP, 33, 2015, p. 428. doi:10.1016/j.procir.2015.06.098
[38] Li, K., Lu, F., Cui, H., Li, X., Tang, X., Li, Z.: Int. J. Adv. Manuf. Technol., 77, 2015, p. 1881. doi:10.1007/s00170-014-6538-4

[39] Cvetković, R. P., Popović, O., Burzić, M., Jovičić, R., Kastelec Macura, S., Buyukyildirim, G.: Int. J. Mater. Res., 104, 2013, p. 18. doi:10.3139/146.110825

[40] Kah, P., Martikainen, J.: Int. J. Adv. Manuf. Technol., 64, 2013, p. 1411. doi:10.1007/s00170-012-4111-6

[41] Bauer, B., Topic, A., Kralj, S., Kožuh, Z.: Mater. Technol., 45, 2011, p. 413. doi: 10.2507/27th.daaam.proceedings. 106

[42] Katayamaa, S., Kawahitoa, Y., Mizuta, M.: Physics Procedia, 5, 2010, p. 9. doi:10.1016/i.phpro.2010.08.024

[43] Liesecki, A.: In: Scientific Proceedings IX International Congress "Machines, Technologies, Materials" 2012. Eds.: Woliński, W. L., Jankiewicz, Z., Romaniuk, R. S. Bellingham, SPIE 2012. doi:10.1117/12.2013431

[44] Liesecki, A.: Archives of Materials Science and Engineering, 58, 2012, p. 209.

[45] Ahn, J., He, E., Chen, L., Dear, J., Davies, C.: J. Manuf. Processes, 29, 2017, p. 62. doi:10.1016/j.jmapro.2017.07.011

[46] Glowacki, M.: J. Phys. D: Appl. Phys., 28, 1999, p. 2051. doi:10.1088/0022-3727/28/10/009

[47] Casalino, G., Campanelli, S. L., Dal Maso, U., Ludovico, A. D.: Procedia CIRP, 12, 2013, p. 151. doi:10.1016/j.procir.2013.09.027

[48] Reisgen, U., Schleser, M., Mokrov, O., Ahmed, E.: Appl. Surf. Sci., 257, 2010, p. 1401. doi:10.1016/j.apsusc.2010.08.042

[49] Lampman, S.: Weld Integrity and Performance: A Source Book Adapted from ASM International Handbooks, Conference Proceedings, and Technical Books. Materials Park, ASM International 1997. ISBN 1615032045

[50] Attar, H., Ehtemam-Haghighi, Sh., Kent, D., Wu, X., Dargush, M. S.: Materials Science and Engineering, 705, 2017, p. 385. doi:10.1016/j.msea.2017.08.103

[51] Li, X., Humbeeck, J., Kruth, P.: Materials and Design, 116, 2017, p. 352. doi:10.1016/j.matdes.2016.12.019

[52] Padilla, E., Jakkali, V., Jiang, L., Chawla, N.: Acta Materialia, 60, 2016, p. 4017. doi:10.1016/j.actamat.2012.03.048

[53] Torkamany, M. J., Malek Ghaini, F., Papan, E., Dadras, S.: Sci. Adv. Mater., 4, 2012, p. 489. doi:10.1166/sam.2012.1307

[54] Takayama, Y., Nomoto, R., Nakajima, H., Ohkubo, Ch..: Dental Materials Journal, 31, 2012, p. 316. doi:10.4012/dmj.2011-158

[55] Takahashi, K., Mehmetli, B., Sato, S.: Welding International, 12, 1998, p. 347. doi:10.1080/09507119809448498

[56] Panwisawas, Ch., Perumal, B., Ward, M., Turner, N., Turner, P., Brooks, J., Basoalto, H.: Acta Materialia, 126, 2017, p. 251. doi:10.1016/j.actamat.2016.12.062

[57] Rudy, J. F., Rupert, E. J.: Welding Journal, 49, 1970, p. 322 .

[58] Wu, S. C., Yu, X., Zuo, R. Z., Zhang, W. H., Xie, H. L., Jiang, J. Z.: Welding Journal, 92, 2013, p. 64.

[59] Sato, S., Matsumoto, J., Okoshi, N.: Journal of Japan Institute of Light Metals, 31, 1976, p. 398. 
doi:10.2464/jilm.26.398

[60] Yadollahi, A., Shamsaei, N.: Int. J. Fatigue, 98, 2017, p. 14. doi:10.1016/j.ijfatigue.2017.01.001

[61] Xiao, R., Zhang, X.: Journal of Manufacturing Processes, 16, 2014, p. 166. doi:10.1016/j.jmapro.2013.10.005

[62] https://fenix.tecnico.ulisboa.pt/downloadFile/39514 2718113/Disk\%20Laser\%20Welding\%20of\%20Alumi nium\%20Rings-Paper.pdf

[63] Gao, M., Chen, C., Hu, M., Guo, L., Wang, Z., Zeng, X.: Applied Surface Science, 326, 2014, p. 181. $\underline{\text { doi:10.1016/j.apsusc.2014.11.136 }}$
[64] Slotwinski, J. A., Garboczi, E. J., Hebenstreit, K. M.: J. Res. Natl. Inst. Stand. Technol., 119, 2014, p. 494. doi:10.6028/jres.119.019

[65] Heim, K., Bernier, F., Pelletier, R., Lefebvre, L.-P.: Case Studies in Nondestructive Testing and Evaluation, 6, 2016, p. 45. doi:10.1016/j.csndt.2016.09.002

[66] Zinelis, S.: Journal of Prosthetic Dentistry, 84, 2000, p. 575. doi:10.1067/mpr.2000.109479

[67] Alfieri, V., Caiazzo, F., Sergi, V.: Procedia CIRP, 33, 2015, p. 406. doi:10.1016/j.procir.2015.06.094 